\title{
紫外．可視微分分光法及び核磁気共鳴法による分光分析学的薬学研究
}

\author{
北村桂介
}

\section{Derivative Spectrophotometric and NMR Spectroscopic Study in Pharmaceutical Science}

\author{
Keisuke KITAMURA \\ Kyoto Pharmaceutical University, 5 Nakauchicho, Misasagi, Yamashina-ku, Kyoto 607-8414, Japan
}

(Received June 13, 2007)

\begin{abstract}
This review starts with an introduction of derivative spectrophotometry followed by a description on the construction of a personal computer-assisted derivative spectrophotometric (DS) system. An acquisition system for inputting digitalized absorption spectra into personal computers and a BASIC program for calculating derivative spectra were developed. Then, applications of the system to drug analyses that are difficult with traditional absorption methods are described. Following this, studies on the interactions of drugs with biological macromolecules by the DS and NMR methods were discussed. An ${ }^{1} \mathrm{H}$ NMR study elucidated that the small unilamellar vesicle (SUV) has a single membrane made of a phosphatidylcholine bilayer, and that chlorpromazine interacts with both the outer and inner layers. ${ }^{13} \mathrm{C} \mathrm{NMR}$ revealed a reduction of the dissociation constants of phenothiazine drugs due to their interaction with SUV. The partition coefficients of phenothiazine, benzodiazepine and steroid drugs in an SUV-water system and the effects of cholesterol or amino lipids content on these partition coefficients were examined by the DS method. The binding constants of phenothiazine drugs to bovine serum albumin (BSA) and the influence of $\mathrm{Na}^{+}, \mathrm{K}^{+}, \mathrm{Cl}^{-}, \mathrm{Br}^{-}$, and $\mathrm{I}^{-}$on these binding constants were determined by DS. It was found that $\mathrm{I}^{-}, \mathrm{Br}^{-}, \mathrm{Cl}^{-}$reduce the binding constants in this order, and that $\mathrm{Na}^{+}$and $\mathrm{K}^{+}$have no effect. ${ }^{19} \mathrm{~F}$ NMR study revealed that triflupromazine binds to BSA and human serum albumin in two regions including Site II with different populations, and that a nonsteroidal anti-inflammatory drug, niflumic acid, binds Sites Ia and Ib.
\end{abstract}

Key words_- derivative spectrophotometry; NMR; interaction; liposome; serum albumin

\section{1. はじめに}

本総説は, 筆者が京都薬科大学薬品分析学教室在 職中に研究のテーマとしたものの中で, 1) パソコ ンを利用する微分分光法の開発研究，2）微分分光 法の薬物分析への応用研究，3）微分分光法及び核 磁気共鳴（NMR）を相補的に用いた薬物と生体マ クロ分子（リポソーム，血清アルブミン）との相互 作用の解明，について記したものである.

筆者は 1975 年ごろから， NMR を用いて薬物と リン脂質リポソームとの相互作用について研究を進 めていたが，その中で，リポソームの脂質二重膜に 入った薬物の定量を行いたいと考えた. しかし，定 量分析に一般的に用いられている吸光分析はリポ

京都薬科大学 (T607-8414 京都市山科区御陵中内町 5) 現住所：(广650-0004 神戸市中央区中山手通 7 丁目 135)

e-mail: kitamura@mb.kyoto-phu.ac.jp

本総説は, 平成 18 年度退官にあたり在職中の業績を中 心に記述されたものである.
ソームによる濁りや光散乱のため適用が困難であり 思案していたところ, 吸収スペクトルを波長で微分 して得られる微分スペクトルでは，バックグランド の影響を消去できる可能性がある1)ということが分 かり, 直ちに微分分光法の基礎研究に着手した，当 時の分光光度計はアナログ式で，スペクトルの微分 は微分回路を持つ電気微分計を用いる方式であり, 筆者らも試作し薬物分析に用いた。一方，初期の パーソナルコンピュータがその頃に世に現れ，筆者 はパソコンを利用したデジタル微分法の開発を開始 した．その後，開発したデジタル微分システムの薬 物分析への応用，及び，本法と NMR を相補的に用 いて，薬物とリポソーム，血清アルブミンとの相互 作用の解明研究を行ってきた，以下に，各テーマに 沿つて記述する.

\section{2. パソコンを利用する微分分光法の開発研究}

2-1. 微分分光法の概要 ${ }^{2}$ 紫外 - 可視吸光分 析法は, 古くから多くの領域で使用されている。し 
かしながら，濁りのある試料や，複数成分試料でシ グナルに重なりがある場合には適用が難しい。ま た，一般にシグナルの線幅が大きく，かつ形状はな だらかで特長が少なく，定性分析には向かない。そ こで，吸光分析の利点を生かしながら，これらの弱 点を改善する目的で登場したのが微分分光法である。

\section{2-1-1. 微分スペクトルとは}

2-1-1-1. 微分スペクトルの形状吸収スペク トルを波長微分して得られる微分スペクトルは，ど のような形状をしているのか，どのような性質を持 つのかは, 実際の吸収スペクトルの真の数学関数形 を知ることは困難であるので，吸収スペクトルをガ ウス関数でシミュレートすることにより理論的に示 すことができる.

Figure 1 (a) はシミュレーションによる吸収スペ クトルで, Fig. 1(b)-(e) はその 1 次 -4 次微分スペ クトルである. 1,3 次の奇数次の微分スペクトル では元の吸収スペクトルの吸収極大波長 $\left(\lambda_{\max }\right)$ で 微分強度は 0 となり横軸（波長）と交差する。した がって， $\lambda_{\max }$ やクロマトグラムのピーク位置などを
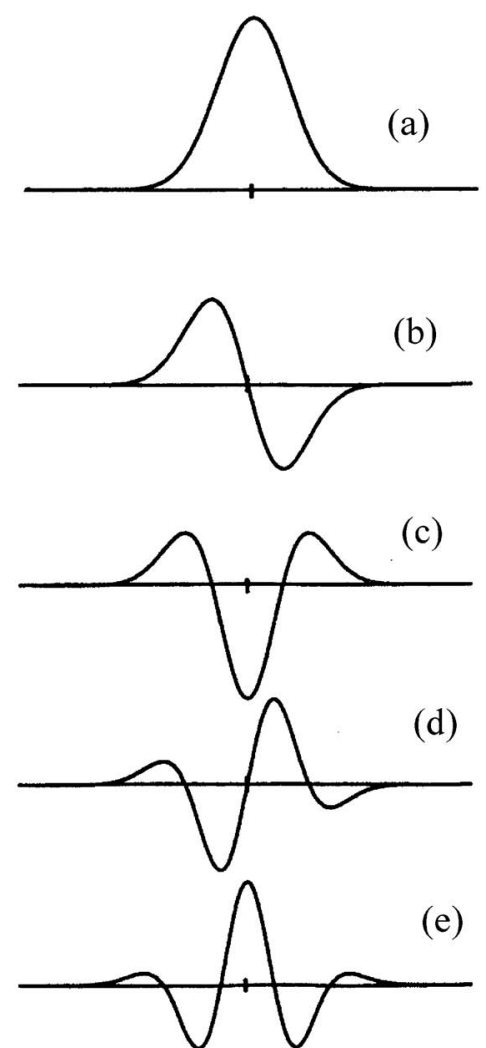

Fig. 1. Differentiation of an Analytical Band Represented by a Gaussian Curve

(a): An analytical band, (b)-(e): First to 4th derivatives of (a).
正確に求めるために，種々のソフトウエアで 1 次微 分スペクトルが利用されている. 偶数次の微分スペ クトルでは最大微分值（絶対值）の波長は $\lambda_{\text {max }}$ に 一致するが， 2 次微分スペクトルでは下に凸，4 次 微分スペクトルでは上に凸となる，いずれも元の吸 収スペクトルより中央の線幅が減少する。

\section{2-1-1-2. 微分スペクトルの強度（微分強度）} 波長 $\lambda$ における吸光度 $A(\lambda)$ は, モル吸光係数を $\varepsilon$ $(\lambda), C, l$ をそれぞれ試料モル濃度 $(\mathrm{M})$, 光路長 $(\mathrm{cm})$ とすると，ベールの法則から， $A(\lambda)=\varepsilon(\lambda)$ $\mathrm{Cl}$ と表される. $A(\lambda)$ を $\lambda$ で $n$ 回微分すると,

$$
\frac{d^{n} A(\lambda)}{d \lambda^{n}}=C l \frac{d^{n} \varepsilon(\lambda)}{d \lambda^{n}}
$$

が得られ，入における微分值，すなわち微分スペク トルの強度は微分次数 $n$ に係わらず $C$ と $l$ に比例 し，ベールの法則が保持されていることが分かる。 したがって, 吸光度と同様, 微分強度を用いて定量 分析が行える.

次に，微分スペクトルではどのような利点が得ら れるのかについて記す。

\section{2-1-2. 微分スペクトルの利点}

2-1-2-1. シグナル分離の向上＼cjkstart高さ及び半值 幅が同じである 2 個のシグナルが強く重なり合った 吸収スペクトルと，その 2 次微分スペクトルを Fig. 2 に示した. Figure 2(a)の吸収スペクトルでは，1 個のピークにしかみえないが，Fig. 2(b)の 2 次微 分スペクトルでは 2 個のピークであることが明らか
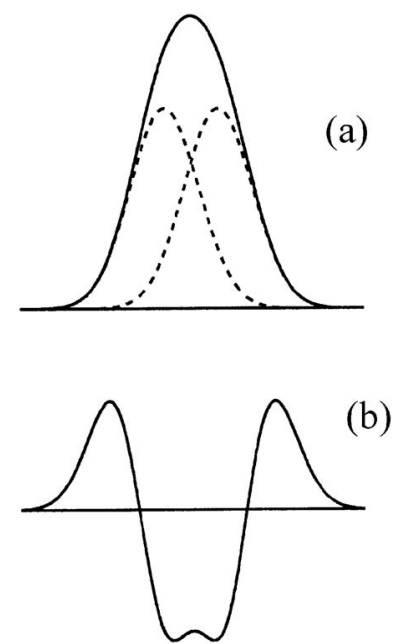

Fig. 2. Resolution Enhancement of Two Overlapping Bands by Second Order Differentiation

(a): Two overlapping bands, (b): Second derivative of (a). 
になっている.4 次微分スペクトルなどより高次の 微分を用いればさらに接近したピークも分離され る.このように微分スペクトルではシグナルの分離 が改善される。

2-1-2-2. スペクトル情報の増強 ガウス関数 によるシミュレーションから $n$ 次微分スペクトル の最大微分強度（絶対值） $D$ は, 吸収スペクトル の半值幅 $W$ の逆数の $n$ 乗に比例することが示され る. したがって, 半值幅が $W_{1}$ と $W_{2}$ の 2 個の吸収 スペクトルの $n$ 次微分スペクトルにおける最大微 分強度の比は, $D_{1} / D_{2}=\left(W_{2} / W_{1}\right)^{n}$ となる，例えば Fig. 3 の例のように, 高さ比 $1: 25$, 半值幅比 $1: 5$ の A， B， 2 個のピークが存在する場合，吸収スペ クトルでは A のピークの存在はほとんど分からな い. しかし， 2 次微分スペクトルでは 2 個のピーク の最大微分強度の比は $(5 / 1)^{2}=25$ となり, $\mathrm{A} の$ ピークの強度は B のピークに比べて 25 倍増大する.

Figure 3(b) のごとく, ピーク A の存在が, 2 次微 分スペクトルでは極めて明瞭に現れていることが分 かる.このように微分スペクトルではスペクトルの 持つ情報が選択的に強調されるため，吸収スペクト ルではほとんど分からないようなシグナルの微細構 造が顕著に出現してスペクトルの特徵が明確とな り，化合物の同定，確認に有効に用いることができ る．また，スペクトルのわずかな変化を強調して検 出することができるため, 種々の応用が期待される.

2-1-2-3. バックグランドシグナルの消去＼cjkstart試 料溶液中の不溶成分による濁りや妨害物質による幅
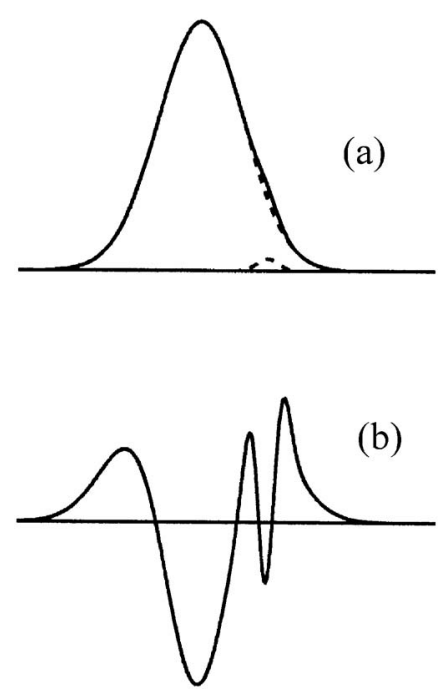

Fig. 3. Enhancement of Spectral Feature (a): A band with a small shoulder, (b): Second derivative of (a)
広い吸収などのバックグランドシグナルが存在する 場合において，バックグランドシグナルが Fig. 4 (a)に示すように波長 $\lambda$ に対して直線的 $(m \lambda+n)$ であるとすると, $\lambda$ による 1 回の微分では定数項 $n$ は消去されるが，勾配の $m$ が定数項として残るた め, 1 次微分スペクトルは Fig. 4 (b) のごとくべー スラインが $m$ だけずれた形になる。しかし，2 回 の微分では, $m$ も消去されるためバックグランド シグナルは完全に消去され，Fig. 4 (c) に示すよう に成分のみの 2 次微分スペクトルが得られる，種々 の要因によるバックグランドシグナルが全域を直線 で近似できる訳ではないが，定量分析に必要な限ら れた波長領域であれば，ほとんどの場合 2 次微分処 理により問題なくバックグランドシグナルは消去さ れる。したがって，微分スペクトルを用いると濁つ た溶液や妨害物質による吸収が重なっている場合で も簡単に定量分析が行え，吸光分析の適用範囲が大 幅に広がることが分かる.

以上，微分分光法の概要について述べたので，次 に，実際の吸収スペクトルから微分スペクトルを得 る方法について筆者らの研究を中心紹介する.

2-2. 微分プログラムの作成とデジタルデータ取 得装置の作製＼cjkstart最初に述べたように，1980 年代 は分光光度計に微分回路を持つ電気微分装置を接続
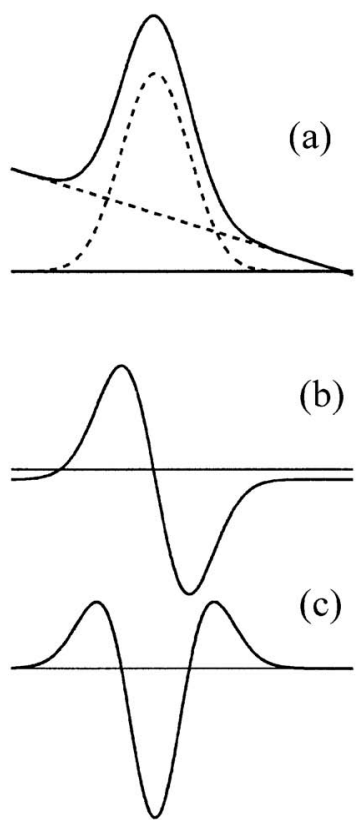

Fig. 4. Elimination of a Linear Matrix Interference (a): A band with a linear matrix interference, (b) - (c) : First and second derivatives of (a), respectively. 
するアナログ微分法が広まつた. ${ }^{4)}$ 筆者らも 1981 年 に電気微分装置を自作し応用研究を行った. ${ }^{3)}$ しか し，1990 年頃には，マイクロプロセッサー内蔵の 分光光度計が使用されるようになり，アナログ微分 法の使用は減少した.

ところで，1980 年頃には BASIC 言語を搭載した 初期のパーソナルコンピュータが現れた．現在のパ ソコンの性能とは比較にならないが，ある程度の数 値計算や制御装置としての使用は可能である。そこ で，筆者はアナログ微分法の薬物分析の研究を行う かたわら，パソコンを利用して Savitzky-Golay 法5) に基づく数值微分（デジタル微分法）により微分ス ペクトルを得る方法の開発に着手した。

Savitzky-Golay 法は多項式近似法の一種で，デジ タル化されたスペクトル上のある点 $\mathrm{P}$ における微 分值を求めるには， $\mathrm{P}$ 点を中心に短波長側，長波長 側に，それぞれ $m$ 個ずつ（合計 $n=2 m+1 ）$ とり， この 1 組のデー夕点を多項式 (2-6 次) に近似する.

すなわち，この 1 組のデー夕点を最もよく通るよう に，その多項式の係数を最小二乗法を用いて求め る. 多項式の各係数が得られたら，P点における微 分值は直ちに計算できるから，順次 $\mathrm{P}$ 点をずらせ て同様の操作を行っていけば微分スペクトルが得ら れる。

Savitzky-Golay 法の特長は，デー夕点の間隔を実 際の波長の值ではなく常に $1, \mathrm{P}$ 点の横座標を 0 と 置き換えて計算することにあり，これによって微分 值の計算は極めて単純化する。.すなわち, 近似多項
式の次数, 微分次数, 1 点の微分值の計算に用いる デー夕点の個数（ $n$ ）によって定まる $n$ 個の整数值 列 $\mathrm{a}_{\mathrm{s}, \mathrm{i}}$ を対応するデー夕点の吸光度 $A_{i}$ に乗じて加 え合せる（コンボリューション）ことによって微分 值 D が計算される.5)

筆者はこの Savitzky-Golay 法に基づくスペクト ルの波長微分プログラムを BASIC 言語で作成し

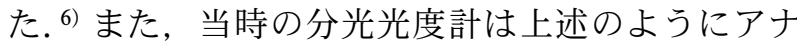
ログ装置であるから，スペクトルをデジタル化して パソコンに入力する必要があり，アナログ-デジタ ル変換ボードや手製の増幅器等を組み込んだデジ夕 ルスペクトルデータ取得システムも作製した. ${ }^{6}$ 当 時の BASIC 言語では 1 秒以下の制御はサポートさ れていないので，この部分のプログラムは機械語で 組まれている，デジタルスペクトルデータ取得シス テムのフローチャートを Fig. 5 に示す. ${ }^{6}$

2-2-1. 紫外 . 可視吸収スペクトルに対するデジ タル微分条件の設定6) 作成した微分プログラム を実際の紫外・可視吸収スペクトルに適用するに は，まず，近似多項式の次数を定める必要がある。 そこで，3 次式及び 5 次式を候補として検討した。 Figure 6(a) は，波長校正に用いられるジジムフィ ルターの紫外・可視吸収スペクトルをデジタルスペ クトルデータ取得システムを用いて得たものである.

Figure 6(b) and (c) は, Fig. 6(a)の吸収スペクトル に対しそれぞれ 5 次式近似， 3 次式近似を用いて求 めた 2 次微分スペクトルである。すべてのピークに ついて 5 次式近似と 3 次式近似で形状に差は認めら

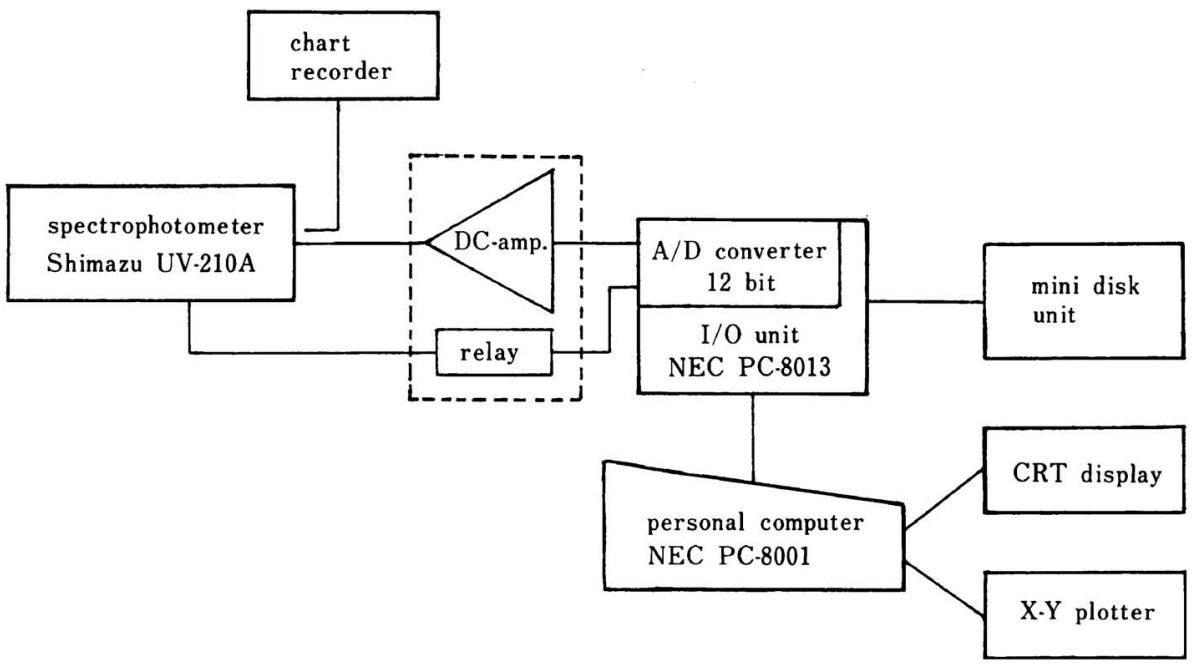

Fig. 5. The Personal Computer Based Digital Spectral Data Acquisition System 


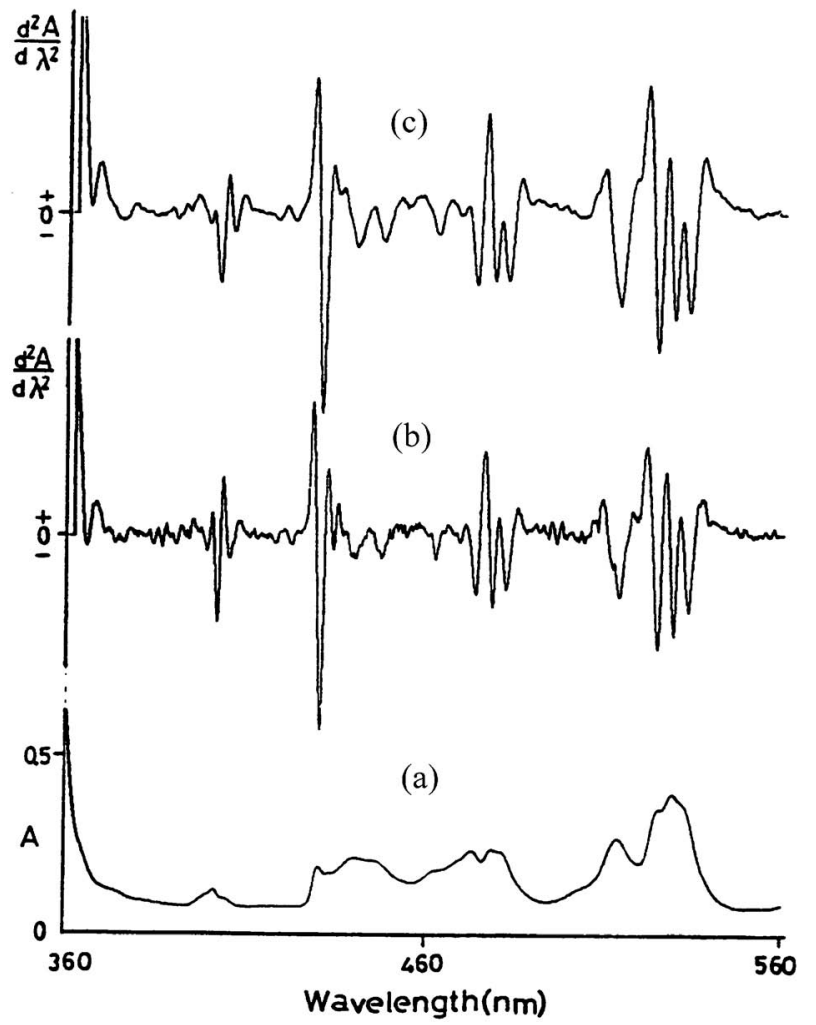

Fig. 6. Dependence of Degree of Polynomials on a Secondderivative Spectrum

(a): Absorption spectrum of a didymium filter, (b)-(c): Secondderivative spectra of (a) obtained by Savitzky-Golay method using quintic (b) and cubic (c) polynomials, respectively.

れず，5次式近似の方がノイズレベルが高くなって いることから，紫外・可視吸収スペクトルに対して は，3 次式近似が適切であると判断した。 ${ }^{6}$

また， 3 次式近似に比して 5 次式近似の方がノイ ズレベルが高くなる理由について理論的な考察を行 つた. ${ }^{7)}$

次に, デー夕点数 $n$, デー夕点間の間隔 $\Delta \lambda$ を定 める必要があるが, 1 点の微分值を求めるについて $(n-1) \Delta \lambda$ の範囲のスペクトルを 3 次式で近似する ことになるから,$n$ と $\Delta \lambda$ を個別に検討する必要は なく，筆者は，デー夕点数 $\mathrm{n}$ を 17 点に固定し， $\Delta \lambda$ を変化させて検討した. $\left.{ }^{6}\right)$

Figure 7 はサリチル酸エタノール溶液を試料とし て上述のシステムでデジタルスペクトルを取得，そ の 2 次微分スペクトルを $\Delta \lambda=0.25-2 \mathrm{~nm}$ の範囲で 変化させて計算したものである. 比較のため 5 次式 近似の結果も示した. Figure 7 より, 3 次式近似で は $\Delta \lambda$ は $0.5 \mathrm{~nm}, 5$ 次式近似では $0.75 \mathrm{~nm}$ が分解能, SN 比の両方に優れていることが分かる。したがっ

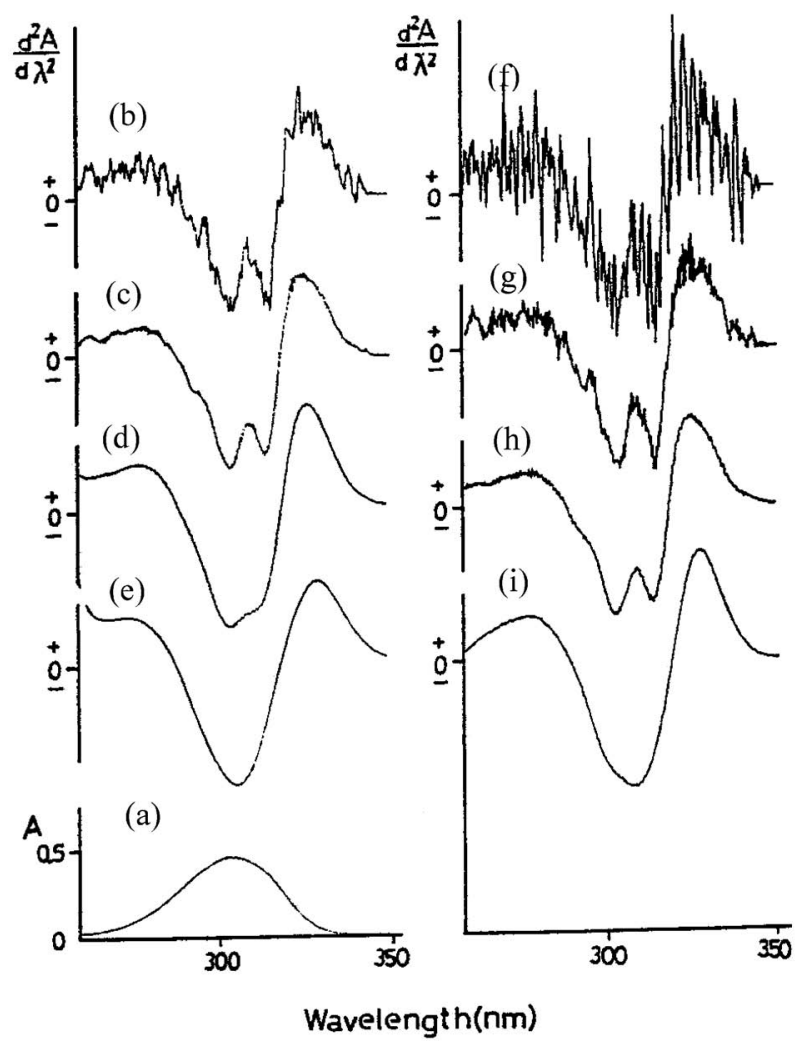

Fig. 7. Effect of $\Delta \lambda$ on the Second-derivative Spectrum of Salicylic Acid in Ethanol

(a): Absorption spectrum of salicylic acid, (b) -(e): Second-derivative spectra of (a) obtained by cubic polynomial convolutions with $\Delta \lambda$ of 2.5 (b), 5.0 (c), 1.0 (d), 2.0 (e) nm, respectively, (f) -(i): Second-derivative spectra of (a) obtained by quintic polynomial convolutions with $\Delta \lambda$ of 2.5 (f), $5.0(\mathrm{~g}), 1.0(\mathrm{~h}), 2.0$ (i) $\mathrm{nm}$, respectively.

て，紫外・可視スペクトルの微分スペクトルを求め るには，3 次式近似を用いて， $\Delta \lambda$ は $0.5 \mathrm{~nm}$ ，ある いは $(n-1) \Delta \lambda$ で設定するなら， $(17-1) \times 0.5=8$ を基準に適宜増減した值を用いればよいという結論 を得た. ${ }^{6}$

2-2-2. 平滑化処理（スムージング）次に, 微 分スペクトルのノイズを軽減するために平滑化処理 (スムージング) について検討した. $\left.{ }^{8}\right)$ スムージング を行うとノイズは減少するが，分解能は悪くなり， ときにはシグナルの劣化を招く危険性があり，民゙の 程度のスムージングが適切かを把握しておく必要が ある．詳細は略すが Savitzky-Golay 法では，0 次微 分の演算を行うことがスムージング処理に当たる.

Figure 8 にサリチル酸エタノール溶液のスペクト ルにスムージング処理を適用した結果を示した.

Figure 8 にみられるように，スムージング処理は有 効に働いてノイズは減少しており，かつ線幅の増加 


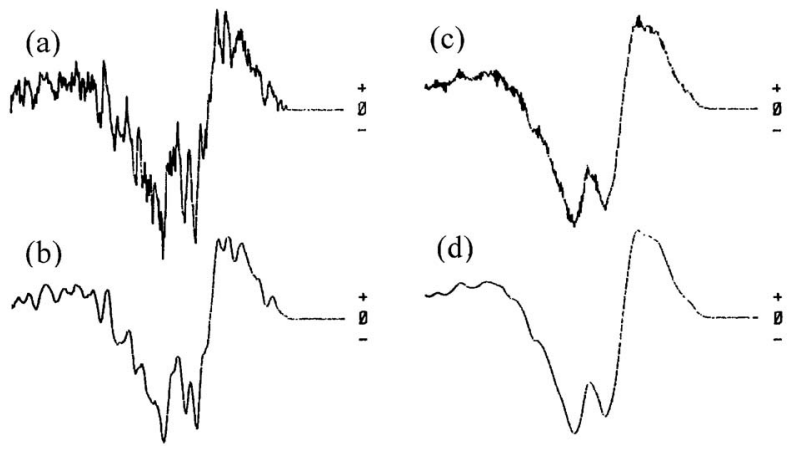

Fig. 8. Effect of Digital Smoothing on a Second-derivative Spectrum of Salicylic Acid in Ethanol

(a): Second-derivative spectrum obtained by the quintic polynomial convolution, (b): Smoothed spectrum of (a), (c): Second-derivative spectrum obtained by the cubic polynomial convolution, (d): Smoothed spectrum of $(\mathrm{c})$

やシグナル高さの減少などの劣化は生じていないの で，スムージング処理が有用であることが示され た. ${ }^{8)}$

上述のごとく，紫外・可視分光光度計からデジタ ルデータを取得するシステムを作製し，微分演算処 理を行うプログラムを作成，さらに演算処理上のパ ラメータの適切な值を定め, パソコンを利用して紫 外・可視微分スペクトルを得るトータルなシステム を構築することができた. ${ }^{6)}$ そこで，このシステム を用いて，従来の吸光分析では満足な結果が得られ なかった種々の薬物分析への応用を試みた．以下に その結果を記す。ただし，一部はアナログ微分で行 つたものも含まれている.

\section{2-3. 薬物分析への応用}

2-3-1. アスピリン原薬, 製剤中の微量サリチル 酸の定量アスピリン中のサリチル酸はサリチル 酸が粘膜障害を起こすことから，原薬については局 方ではその含量が $0.05 \%$ 以下と定められていた。 しかし，その正確な定量は HPLCを用いてもかな

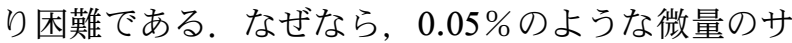
リチル酸は試料溶液を作成する段階でのアスピリン の加水分解によって容易に生じ，かつ逆相クロマト グラフィーの溶離液は水を含んでいるため溶離液中 での加水分解も無視できない.

筆者らは自作の電気微分装置を用いた 2 次微分分 光法により, アスピリン共存のままで, 含量 0.005 \%のサリチル酸の定量を可能にした. ${ }^{3)}$ すなわち, 数千倍も存在するアスピリンの吸収帯のすその部分 にサリチル酸のシグナルが重なっているが，2 次微
分することによりアスピリンの吸収帯のすその部分 の影響は消去され，アスピリンの濃度の影響を全く 受けず定量が行えた。本法は，アスピリン原薬を加 水分解を抑えるためのクエン酸を含むエタノールに 溶解し，微分スペクトルを測定するだけでよく，極 めて簡便で短時間に行える，筆者らの報告後も HPLC による研究報告が続いているが, 9) 20 年後の 2003 年の報告10)においても，正確さ，簡便さとも に，筆者らの微分分光法を上回るとは言い難い.

一方，製剂の分析は通常，製剂添加物を除くため 製剂からの薬物の抽出が必要である.この抽出物に ついて吸光分析， HPLC 分析等が行われる。しか しながら，微分分光法においては濁り等によるバッ クグランド吸収の影響を受けないため，単に試料を 測定溶媒に溶解するだけで測定が可能となる。した がつて，操作が極めて短時間でかつ誤差を伴う抽出 等の前処理が不要なため正確な定量值を得ることが 容易である．筆者らはアスピリン製剤（錠剤）中の アスピリンと不純物のサリチル酸の同時定量を，錠 剂を粉砕後溶媒に溶解した試料溶液の 2 次微分スペ クトルを用いて行った. ${ }^{11)}$ Figure 9 (a) に示すよう に，吸収スペクトルの吸光度（図中の $A$ ） では不 溶の錠剂添加物の濁りによる大きな吸収とアスピリ ンの吸収帯のすそ部分がバックグランドシグナルと なってサリチル酸のピークと重なっている。しかし Fig. 9(b)の 2 次微分スペクトルでは完全にバック グランドシグナルが消去されているため, 図中の Dからサリチル酸の正確な定量が行えた。 ${ }^{11)}$

また，座薬については，HPLC 分析では大量に 存在する座薬基材と薬物を分離する必要があり，時 間と労力を要するほか, 分離処理中のアスピリンの サリチル酸への加水分解を抑える工夫が不可欠であ る.しかしながら，2 次微分分光法では座薬をその まま試料溶媒に溶解し 2 次微分スペクトルを測定す ることによって，基材に基づくバックグランドシグ ナルは消去され正確な定量が可能となった. ${ }^{12}$

以上のごとく，アスピリン製剤を例として，製剤 分析において 2 次微分分光法は分離手段を必要とせ ず定量できる簡便で優れた手法であることを実証し た.

2-3-2. その他の製剤分析薄層クロマトグラ フィー（TLC）は多成分系試料の分離や純度の検 定に多用される簡便な分析手段であるが，定量分析 


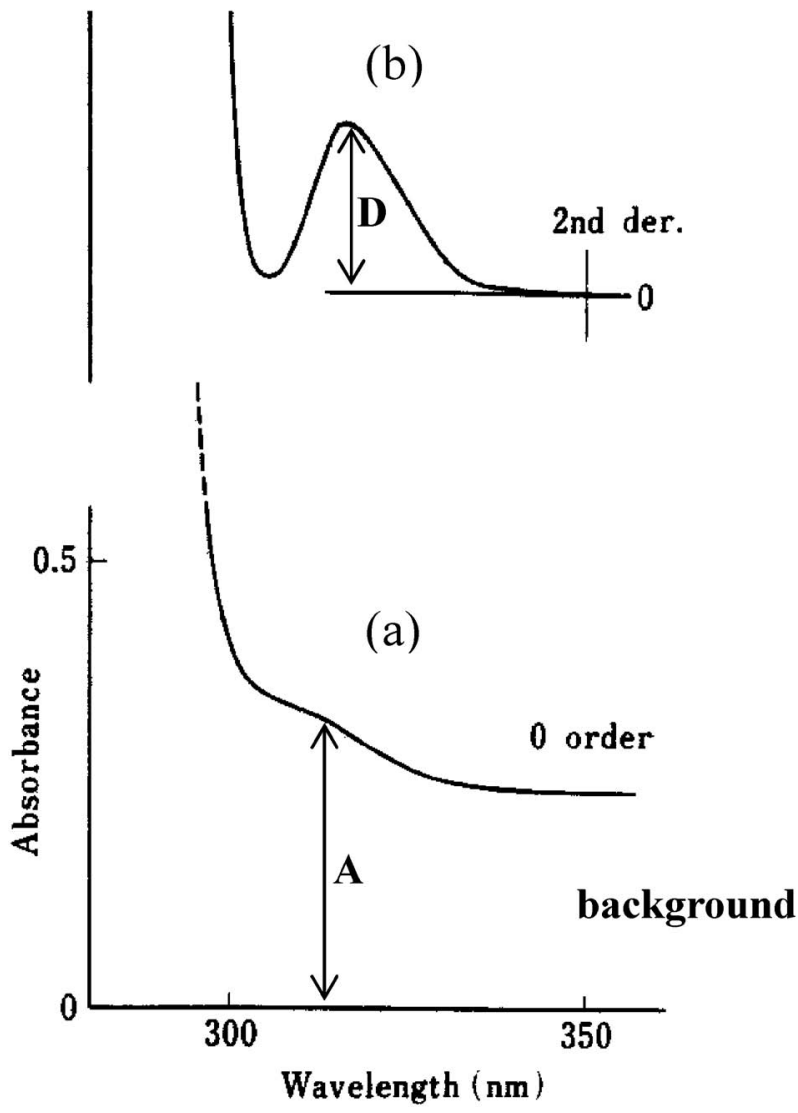

Fig. 9. Absorption (a) and Second-derivative (b) Spectra of an Ethanol Solution of Aspirin with Tablet Excipients

には，デンシトメーターやスポットのスキャンニン グ，あるいは掻き採りスポットの溶媒抽出物の吸光 分析が適用される．筆者らは掻き採りスポットを測 定溶媒に溶解し，固定相粉末が浮遊したままで微分 分光法を用いて錠剤中のイソニアジド定量を行い, 微分分光法が TLC スポットの簡便で正確な定量法 として活用できることを示した. ${ }^{13)}$

近年，筆者らは，FT-ラマンスペクトルによる製 剤中の結晶多形の分析にも微分スペクトルが有効で あることを示した. ${ }^{14)}$

2-3-3. 微分スペクトルのカーブフィッティング による製剤中の 2 成分の同時定量 ${ }^{15)} 2$ 成分同時 定量の例として，アスピリンーカフェイン散剤につ いて検討した。製剤添加物除去の前処理を行わず， 試料を直接測定溶媒に溶解した濁りのある測定液の 2 次微分スペクトルには濁りによるバックグランド シグナルの影響は除かれている。しかし，アスピリ ンとカフェインのスペクトルの重なりは強く, 2 次 微分スペクトルにおいても分離したシグナルは得ら<smiles>[R]c1ccc2c(c1)N(CCCN(C)C)c1ccccc1S2</smiles>

$\mathrm{R}=\mathrm{H}: \mathrm{PZ}, \quad \mathrm{R}=\mathrm{Cl}: \mathrm{CPZ}, \quad \mathrm{R}=\mathrm{CF}_{3}: \mathrm{TFZ}$

Fig. 10. Chemical Structures of Phenothiazine Drugs

れない，そこで，2次微分スペクトルについてカー ブフィッティングを行うことにより，両薬物の定量 ができた. ${ }^{15)}$

このように，製剤中の 2 成分の同時定量において も, 抽出操作をすることなく, 2 次微分スペクトル のパソコン処理で同時定量が行えることを示した.

2-3-4. 難溶性薬物の酸解離定数（ $\left.\mathrm{p} \boldsymbol{K}_{\mathrm{a}}\right)$ の測定 ${ }^{16)}$ 微分分光法は定量分析法としてだけでなく, 難溶性 薬物の酸解離定数 $\left(\mathrm{p} K_{\mathrm{a}}\right)$ の測定にも有効である. 筆者らは水に難溶性の 3 種のフェノチアジン系薬物 (Fig. 10), chlorpromazine (CPZ) hydrochloride, promazine (PZ) hydrochloride, triflupromazine （TFZ） hydrochlorideの $\mathrm{p} K_{\mathrm{a}}$ を 2 次微分スペクトル を用いて測定した.

薬物には $\mathrm{CPZ} \cdot \mathrm{HCl}$ のように弱塩基の塩酸塩で あるものがかなり存在するが, $\mathrm{CPZ} ・ \mathrm{HCl}$ は水溶液 中で, $\mathrm{CPZ} \cdot \mathrm{HCl} \leftrightarrows \mathrm{CPZH}^{+}+\mathrm{Cl}^{-}$で示される解離 平衡にある。すなわち, $\mathrm{CPZ} て ゙ は-\mathrm{N}\left(\mathrm{CH}_{3}\right)_{2}$ 基がプ ロトン化されて $-\mathrm{N}^{+} \mathrm{H}\left(\mathrm{CH}_{3}\right)_{2}$ となる. ${ }^{-\mathrm{N}^{+}} \mathrm{H}\left(\mathrm{CH}_{3}\right)_{2}$ はさらにその一部が加水分解されて-N $\left(\mathrm{CH}_{3}\right)_{2}$ と $\mathrm{H}^{+}$ に解離する. 生体膜を透過できるのは- $\mathrm{N}\left(\mathrm{CH}_{3}\right)_{2}$ を 持つ中性の分子型であるので, 分子型の存在量を決 定する解離定数 $\mathrm{p} K_{\mathrm{a}}$ は薬物の重要な物性值である.

一般に $\mathrm{p} K_{\mathrm{a}}$ の測定は水溶液中で電位差滴定によ り行われるが，CPZのように分子型の溶解度が低 い場合は $\mathrm{pH}$ が高くなると分子型が増加し不溶とな つて析出するため, 滴定の続行が不可能になる。こ のためエタノール等の水溶性有機溶媒を加えた混合 水溶液中で滴定が行われているが，このときの $\mathrm{p} K_{\mathrm{a}}$ 值は加えた有機溶媒の種類や量によって水溶液中の 值とは異なってしまう。そこで筆者らは以下の理論 に基づき 2 次微分分光法を適用し，簡便で正確な $\mathrm{p} K_{\mathrm{a}}$ 測定法を開発した. ${ }^{16)}$

いま, $\mathrm{CPZ}$ の分子型の溶解度（飽和濃度）を $S_{0}$ $[\mathrm{M}]$, 分子型とイオン型合計の溶解度を $S[M]$, 解 
離定数を $K_{\mathrm{a}}$ とすると, 溶液中の水素イオン濃度 $\left[\mathrm{H}^{+}\right]$に対し， $S=S_{0}\left[\mathrm{H}^{+}\right] / K_{\mathrm{a}}+S_{0}$ の関係がある. ${ }^{16)}$ したがって，種々の $\mathrm{pH}$ における $\mathrm{CPZ}$ の溶解度 $S$ を測定すれば，上式から $K_{\mathrm{a}}$ 及び $S_{0}$ を求めることが できる。しかし， $S$ を求めるため，ある $\mathrm{pH}$ の緩衝 液に $\mathrm{CPZ}$ を過剩に加え飽和させると, 不溶の $\mathrm{CPZ}$ は油滴となって析出するため試料溶液に濁りを生じ,

Fig. 11 (a)に示すようにバックグランドシグナルの ためべースラインが上昇する，このため，吸光度を 用いて溶解している $\mathrm{CPZ}$ の濃度 $S$ を求めることは できない，そこで，このスペクトルに 2 次微分処理 を行うと, Fig. 11(b)に示すようにバックグランド シグナルは消失してベースラインは 0 を通り，濁り による影響が消去される. Figure 11 (b) の微分值 $D$ は $S$ に比例するから，上式は $D=D_{0}\left[\mathrm{H}^{+}\right] / K_{\mathrm{a}}+D_{0}$ と書き換えられ， $\left[\mathrm{H}^{+}\right]$と $D$ は直線関係を示すか ら，切片と勾配から $D_{0}$ と $K_{\mathrm{a}}$ が得られる。実測し た $\left[\mathrm{H}^{+}\right]$と $D$ をプロットしたところ良好な直線が得 られ，極めて再現性よく $K_{\mathrm{a}}\left(\mathrm{p} K_{\mathrm{a}}\right)$ を求めることが できた.

\section{2-3-5. ゼロ点交差法による CPZ と $\beta$-cyclodex-} trin の包接結合定数の測定 ${ }^{17)}$

Figure 1 に示した ように微分スペクトルには横軸と交差する点（ゼロ 点）がある.この点では微分強度は 0 であるから， ある物質について濃度を変えて微分スペクトルを測 定しても濃度に係わらずすべてこのゼロ点を通過す
る.したがって， 2 成分からなる試料溶液の微分ス ペクトルを測定した場合，両成分のゼロ点が一致し ない限り，一方のゼロ点における微分強度は他方の 成分の夕の微分強度を表す。これらのゼロ点での微 分強度を用いれば，2 成分の同時定量が可能とな

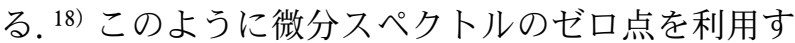
る方法をゼロ点交差法（zero-crossing method）と いう.

筆者らはゼロ点交差法を用いて chlorpromazine の $\beta$-cyclodextrin による包接の結合定数を求め た. ${ }^{17)}$ 本法は, chlorpromazine に限らず, cyclodextrin に包接されることにより吸収スペクトルに変化 が生じる多くの薬物の結合定数の測定に簡便に適用 できる方法である.

以上，筆者はパソコンを利用したデジタル微分法 を開発し，その結果に基づき従来の紫外・可視吸光 分析では困難であった種々の薬物分析に応用するこ とにより，吸光分析の適用範囲を大きく拡大するこ とができた。

3. 微分分光法及び NMR 法による薬物ーリポ ソーム相互作用の解明研究

リン脂質, 特に phosphatidylcholine（PC）は生 体膜の主要構成物質であり, 生体膜は PC による二 重膜を基本構造としていることはよく知られている. $\mathrm{PC}$ を水中に分散させると同心円状の多層の二重膜 からなる large multilamellar vesicles（LMV）を生じ
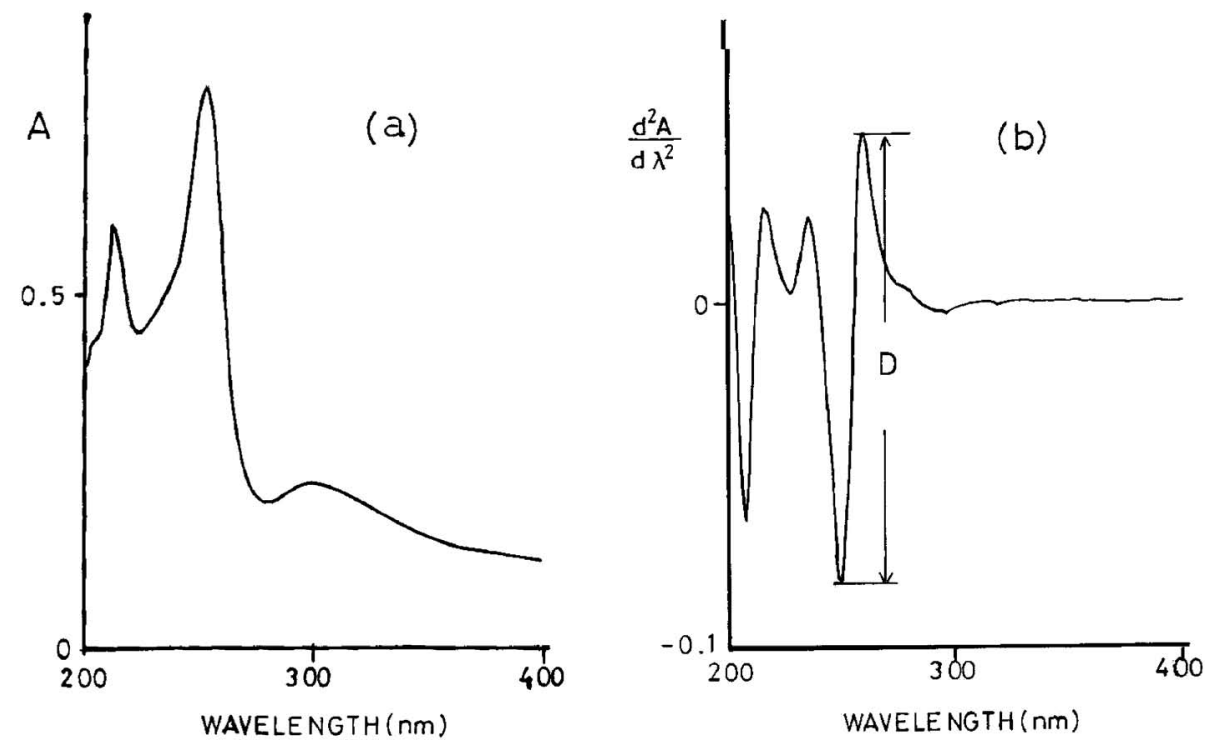

Fig. 11. Absorption (a) and Second-derivative (b) Spectra of a Turbid Sample Solution Prepared by Adding an Excess Amount of $\mathrm{CPZ} \cdot \mathrm{HCl}$ to a Buffer of $\mathrm{pH} 9.30$ 
る． LMV 懸濁液に超音波処理を行うと，直径が約 $20 \mathrm{~nm}$ で，生体膜と同様の一層の二重膜からなる小 胞 small unilamellar vesicles（SUV）が生じる. LMV，SUVはリポソームと総称されているが，生 体膜モデルとして用いられるのは SUV である.

薬物は生体に投与されると吸収，組織移行におい て生体膜を通過するが，多くの薬物は生体膜を受動 輸送される。したがって，脂質二重膜との相互作用 は薬物の生体との相互作用の基本的なものであり, 強く興味の持たれるところである.

\section{3-1. NMRによる研究}

\section{3-1-1. 1H NMR}

3-1-1-1. フェノチアジン系薬物と PC リポソー 厶の相互作用の解明 筆者は 1975 年ごろから SUV を用い，フェノチアジン系薬物をモデル薬物 として，薬物と生体膜の相互作用について，NMR による研究を続けてきた. Chlorpromazine（CPZ） を代表とするフェノチアジン系薬物は向精神薬とし て古くから広く用いられている薬物であり，薬効と は別に生体膜への直接的作用も知られている.

Figure 12 (a) は $60 \mathrm{MHz}$ の装置で測定した重水中 の PC SUV の ${ }^{1} \mathrm{H}$ NMR スペクトルである. SUV は多数の PC 分子からなる分子量 200 万程度のマク 口分子であるが，SUV を形成している PC の脂肪 酸鎖の methylene 基，末端の methyl 基，及び choline methyl 基がシグナルとして観測されている. ${ }^{19)}$

この試料溶液にシフト試薬である $\mathrm{Eu}^{3+}$ を加える と (Fig. 12(b)), PC 二重膜は $\mathrm{Eu}^{3+}$ を透過させな いので, $\mathrm{Eu}^{3+}$ は二重膜の外側の $\mathrm{PC}$ 層（厳密には 負電荷を帯びているリン酸残基）のみに接近し，外 側の PC の choline methyl を高磁場シフトさせる.

一方，内側の choline methyl 基は $\mathrm{Eu}^{3+}$ が近づき得 ないのでシフト変化は起こらず，結果として Fig. 12 (b)のごとく choline methyl は外側（高磁場側） と内側の 2 本に分裂する。すすなわち，SUV が二重 膜構造であることを ${ }^{1} \mathrm{H}$ NMR スペクトルで証明で きた. ${ }^{19)}$

Figure 13 は $\mathrm{Eu}^{3+}$ を含む Fig. 12(b)の試料溶液に $\mathrm{CPZ}$ を順次添加した場合の choline methyl の ${ }^{1} \mathrm{H}$ NMR シグナルを示している. CPZ の添加に伴 い外側の choline methyl が示す高磁場側のシグナル は低磁場に移動し，ついには元の 1 本のシグナルに 戻っている。これは添加した CPZ が PC SUV 表面 (a)

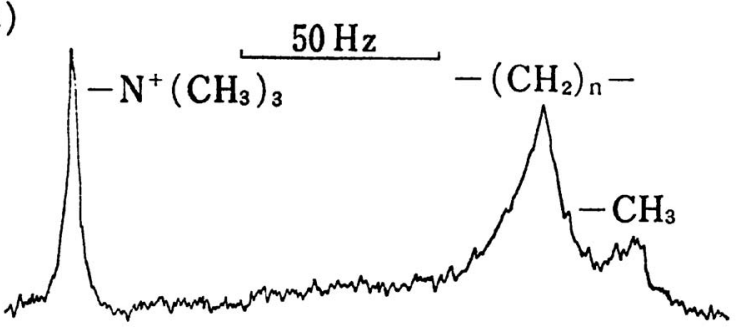

(b)

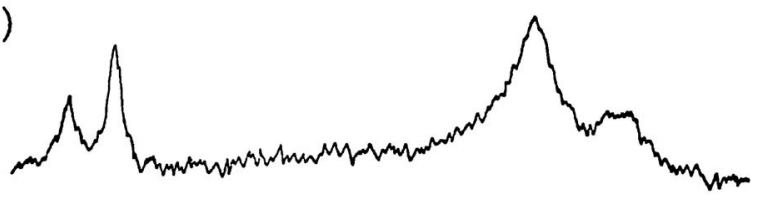

Fig. 12. ${ }^{1} \mathrm{H}$ NMR Spectra of PC SUV in $\mathrm{D}_{2} \mathrm{O}$ in the Absence (a) and Presence (b) of $9.6 \mathrm{mM} \mathrm{Eu}^{3+}$

(a)

(b)

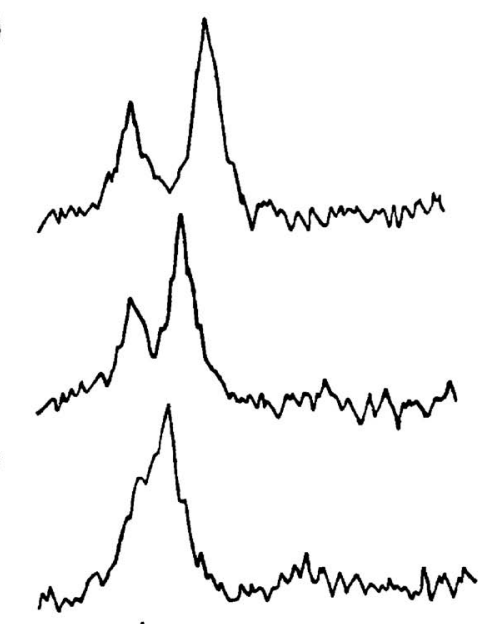

(d)

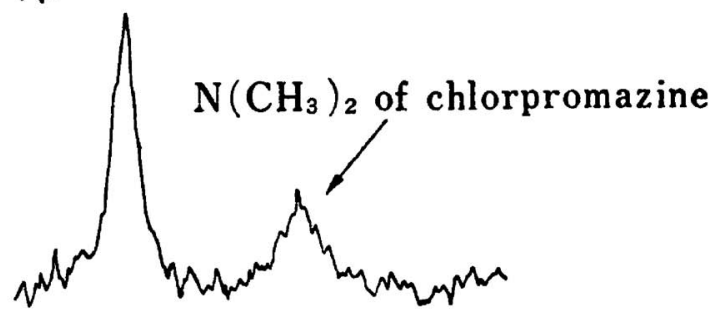

$50 \mathrm{~Hz}$

Fig. 13. Effect of $\mathrm{CPZ}$ on the ${ }^{1} \mathrm{H}$ NMR Signal Splitting of Choline Methyl of PC SUV in a $\mathrm{D}_{2} \mathrm{O}$ Solution Containing $9.6 \mathrm{mM} \mathrm{Eu}^{3+}$

CPZ concentrations (mM): (a) 0, (b) 4.9, (c) 11, (d) 21 .

に相互作用し，SUV 表面から $\mathrm{Eu}^{3+}$ を排除したこ とを示している.このことから，CPZが SUV 表面 に直接相互作用していることが証明された. ${ }^{19)}$

さらに，筆者らは低磁場シフトを誘起する $\mathrm{Pr}^{3+}$ を内液に含有し，高磁場シフトを誘起する $\mathrm{Eu}^{3+}$ を 
外液に含む PC SUV 試料を作製した。この試料溶 液に順次 $\mathrm{CPZ}$ を添加して ${ }^{1} \mathrm{H} \mathrm{NMR}(100 \mathrm{MHz})$ を 測定すると，低磁場シフトした内側の choline methyl と高磁場シフトした外側の choline methyl の両シグナルは CPZ 濃度依存的に元の位置に移動 することを見出した。このことによって，CPZ は 二重膜を透過して内側の PC 相とも相互作用するこ とを明らかにした. ${ }^{20)}$

その後, 超伝導磁石 NMR の登場によりリポソー ムのより高分解能な NMR スペクトルが得られるよ うになり，また種々の多重共鳴手段が紹介された。 筆者らは CPZ と PC SUV の相互作用に関して, ${ }^{1} \mathrm{H}$ ${ }^{1} \mathrm{H}$ NOE (Nuclear Over Hauser Effect) を $200 \mathrm{MHz}$ の装置で測定し，CPZ のフェノチアジン環は二重 膜構成 PC 分子のカルボニル基に隣接する $\alpha$-methylene にまで及んでいること，また- $\mathrm{NH}^{+}\left(\mathrm{CH}_{3}\right)_{2}$ 基は PC SUV のリン酸エステル基と相互作用して いることを明らかにした。 ${ }^{21)}$

3-1-1-2. アルミニウムと PC 二重膜との相互作 用アアルミニウムはアルツハイマー病の原因の 1 つであるとする説があり，それに関連して，生体内 において脂質の過酸化を促進するという報告もあ る. ${ }^{22)} し か し ， \mathrm{Al}^{3+}$ が生体膜と直接相互作用をす るかどうかについては不明であった．筆者は上述と 同様にしてシフト試薬 $\mathrm{Eu}^{3+}$ により内側と外側の 2 本に分裂した PC リポソームの choline methyl シグ ナルが，種々の金属イオンを添加した場合に外側の choline methyl シグナルが元の位置へ戻る度合でも って各金属イオンの PC 二重膜との相互作用の大き さを比較した。その結果, $\mathrm{Mg}^{2+}, \mathrm{Ca}^{2+}, \mathrm{Ni}^{2+}$, $\mathrm{Zn}^{2+}$ はほとんどシグナルに変化を生じなかったの で，これらの金属イオンは PC 二重膜と直接には相 互作用しないことが確認されたが， $\mathrm{Al}^{3+}$ は濃度依 存的に外側の choline methyl の高磁場シフトを減少 させたため, $\mathrm{Al}^{3+}$ が PC 膜と直接相互作用するこ とが実証された. ${ }^{23)}$

\section{3-1-2. ${ }^{13} \mathrm{C}$ NMR $\quad{ }^{13} \mathrm{C}$ NMR $は{ }^{1} \mathrm{H}$ NMR より} もシグナルの分離がはるかによいので, 詳細な知見 が得られる。 Figure 14 に PC SUV の ${ }^{13} \mathrm{C}$ NMR （20 MHz） スペクトルを示したが， ${ }^{1} \mathrm{H}$ NMR に較 ベて高分解能スペクトルであることが分かる，特に ${ }^{1} \mathrm{H}$ NMR では得られない PC 分子の脂肪酸鎖の力 ルボニル炭素が観測されている。筆者らは

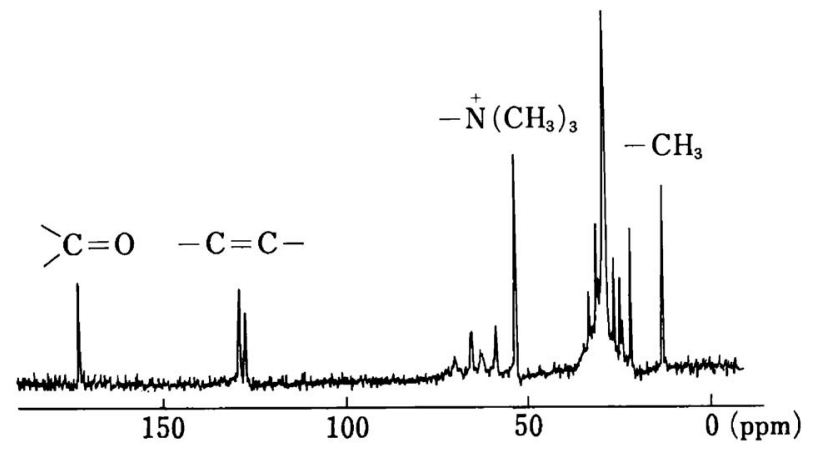

Fig. 14. ${ }^{13} \mathrm{C}$ NMR Spectrum of PC SUV in $\mathrm{D}_{2} \mathrm{O}$

${ }^{1} \mathrm{H}$ NMR と同様にシフト試薬を使用して，CPZ と の相互作用がリポソーム二重膜を構成している PC 分子のカルボニル基に及んでいることを確認し た. ${ }^{24)}$

3-1-2-1. PC 二重膜と相互作用しているフェノチ アジン系薬物の $\mathrm{p} K_{\mathrm{a}}$ の測定 前述の 2 次微分ス ペクトル法により，フェノチアジン系薬物の $\mathrm{p} K_{\mathrm{a}}$ が 9.4 近辺であることを明らかにしたが, 16) この值 から計算すると，生理的 $\mathrm{pH}$ である $\mathrm{pH} 7.4$ の溶液 中のフェノチアジン系薬物は $99 \%$ 近くがイオン型 （カチオン）である。しかし，PC二重膜を通過で きるのは電荷を持たない中性の分子であるとされて いるにも係わらず，前述の NMR の結果では, CPZ は PC 二重膜を容易に通過して内側 PC 層と も相互作用している. ${ }^{20)}$

一方，同じ NMR の結果 ${ }^{19-21)}$ から PCリポソーム と相互作用しているフェノチアジン系薬物の $-\mathrm{NH}^{+}$ $\left(\mathrm{CH}_{3}\right)_{2}$ 基は膜表面近傍に存在することが分かって いる。したがって, $-\mathrm{NH}^{+}\left(\mathrm{CH}_{3}\right)_{2}$ 基の存在する環 境はバルクの水相とは異なっており，このような状 況のフェノチアジン系薬物の $\mathrm{p} K_{\mathrm{a}}$ は水中における 值と異なるのではないかと考えられる。そこで PC リポソームと相互作用しているフェノチアジン系薬 物の $\mathrm{p} K_{\mathrm{a}}$ を測定することを考えた。

通常， $\mathrm{p} K_{\mathrm{a}}$ は電位差滴定で測定されるが， $\mathrm{PC}$ ポソームと相互作用している薬物を電位差滴定する ことは困難である。そこで， $-\mathrm{NH}^{+}\left(\mathrm{CH}_{3}\right)_{2}$ 基の ${ }^{1} \mathrm{H}$

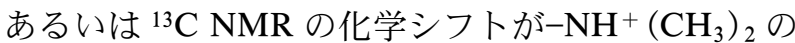
解離状態によって異なることを利用して，試料溶液 (緩衝液) の $\mathrm{pH}$ とその化学シフトの関係から $\mathrm{p} K_{\mathrm{a}}$

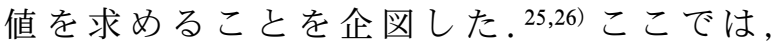
${ }^{13} \mathrm{C}$ NMR の場合について述べる。 
まず，薬物に比して多量に存在する PC リポソー ムのシグナルの中から薬物のシグナルを観測するた めに, $-\mathrm{N}\left(\mathrm{CH}_{3}\right)_{2}$ 基の 1 個の $\mathrm{CH}_{3}$ 基を ${ }^{13} \mathrm{C}$ でラべ ルした 3 種のフェノチアジン系薬物, ${ }^{13} \mathrm{C}-\mathrm{CPZ},{ }^{13} \mathrm{C}$ triflupromazine (TFZ), ${ }^{13} \mathrm{C}$-promazine $(\mathrm{PZ})$ を合成

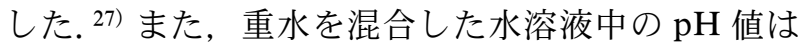
通常の水溶液中での值と若干のずれがあるため ${ }^{25)}$, 外部ロックを用いて，重水を全く含まない完全な水 溶液（緩衝液）を用いて ${ }^{13} \mathrm{C}$ NMR を測定した。

Figure 15 にPCリポソーム緩衝液（pH 7.4）中 の ${ }^{13} \mathrm{C}-\mathrm{PZ}(200 \mu \mathrm{M})$ の ${ }^{13} \mathrm{C} \mathrm{NMR}(75 \mathrm{MHz})$ スペ クトルを示した。内部基準には，試料溶液の $\mathrm{pH} の$ 影響を受けないことと，基準物質添加による試料溶 液への影響を避けるため, リポソームを構成してい る $\mathrm{PC}$ 分子の脂肪酸鎖の末端 $\mathrm{CH}_{3}$-基のシグナルを 用いた. Figure 15 において，30 ppm 近傍のシグナ ルが ${ }^{13} \mathrm{C}-\mathrm{PZ}$ の $N$-dimethyl 基である。また， 40 ppm 近傍の強いシグナルは PC の choline methyl 基 によるものである. ${ }^{26}$

$\mathrm{PC}$ 二重膜と相互作用している ${ }^{13} \mathrm{C}-$ フェノチアジ ン系薬物の $N$-dimethyl 基の化学シフトについて, 試料溶液の $\mathrm{pH}$ を低くしてすべてがプロトン化され たときの化学シフトを $S_{\mathrm{c}}, \mathrm{pH}$ を高くしてすべてが 非プロトン化されたときの化学シフトを $S_{\mathrm{n}}$ とする と，ある $\mathrm{pH}$ における $N$-dimethyl 基の化学シフト

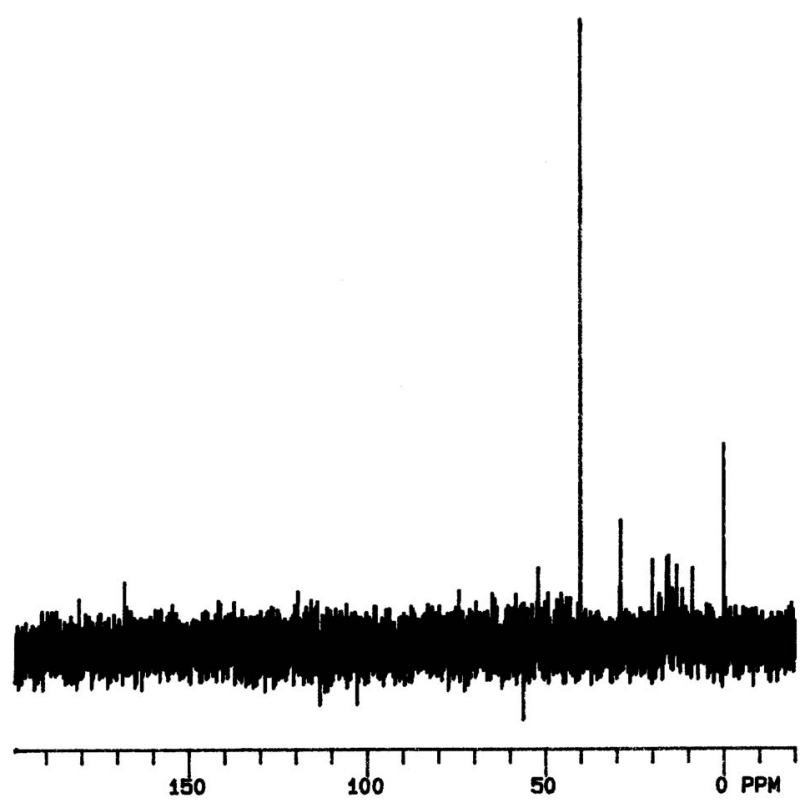

Fig. 15. ${ }^{13} \mathrm{C}$ NMR (75 MHz) Spectrum of $200 \mu \mathrm{M}{ }^{13} \mathrm{C}-\mathrm{PZ}$ in Phosphate Buffer ( $\mathrm{pH} 7.4$ ) containing $27 \mathrm{~mm}$ PC SUV at 21 ${ }^{\circ} \mathrm{C}$
$S_{\mathrm{o}}$ は，プロトン化と非プロトン化の間のプロトン 交換速度が ${ }^{13} \mathrm{C}$ NMR（75 MHz）において十分早い 場合， $S_{\mathrm{o}}=P_{\mathrm{c}} \cdot S_{\mathrm{c}}+P_{\mathrm{n}} \cdot S_{\mathrm{n}}$ と表される.ここで, $P_{\mathrm{c}}$, $P_{\mathrm{n}}$ はそれぞれ相互作用している ${ }^{13} \mathrm{C}-$ フェノチアジ ン系薬物のプロトン化，非プロトン化している分子 数の割合 (分率) である. 次に, $\mathrm{p} K_{\mathrm{m}}$ を $\mathrm{PC}$ 二重膜 と相互作用している ${ }^{13} \mathrm{C}-$ フェノチアジン系薬物の 解離定数とすると， $S_{0}$ は次のように表すことがで きる. ${ }^{26)}$

$$
S_{\mathrm{o}}=\left(10^{-\mathrm{pH}} \cdot S_{\mathrm{c}}+10^{-\mathrm{p} K_{\mathrm{m}}} \cdot S_{\mathrm{n}}\right) /\left(10^{-\mathrm{pH}}+10^{-\mathrm{p} K_{\mathrm{m}}}\right)
$$

上式に非線形最小二乗法を適用した BASIC 言語 によるプログラムを作成し，試料溶液の $\mathrm{pH}$ 值と $S_{\mathrm{o}}$ の実測值を用いて $\mathrm{p} K_{\mathrm{m}}$ の值を求めた. Figure 16 は試料溶液の $\mathrm{pH}$ 值と $S_{\mathrm{o}}$ の実測值をプロットした ものであり，実線は得られた $\mathrm{p} K_{\mathrm{m}}$ を上式に代入し て描いた理論曲線である。各実測值は理論曲線上に 乗っており，得られた $\mathrm{p} K_{\mathrm{m}}$ 值が妥当なものである ことを示している.

3 種のフェノチアジン系薬物について得られた $\mathrm{p} K_{\mathrm{m}}$ 值は，いずれも水溶液中の $\mathrm{p} K_{\mathrm{a}}$ 值よりも約 1 低下することが明らかとなった. ${ }^{26)}$ すなわち, $\mathrm{pH}$ 7.4 においては PC 二重膜に侵入したフェノチアジ ン系薬物の中性分子型は，水溶液中の $\mathrm{p} K_{\mathrm{a}}$ 值から

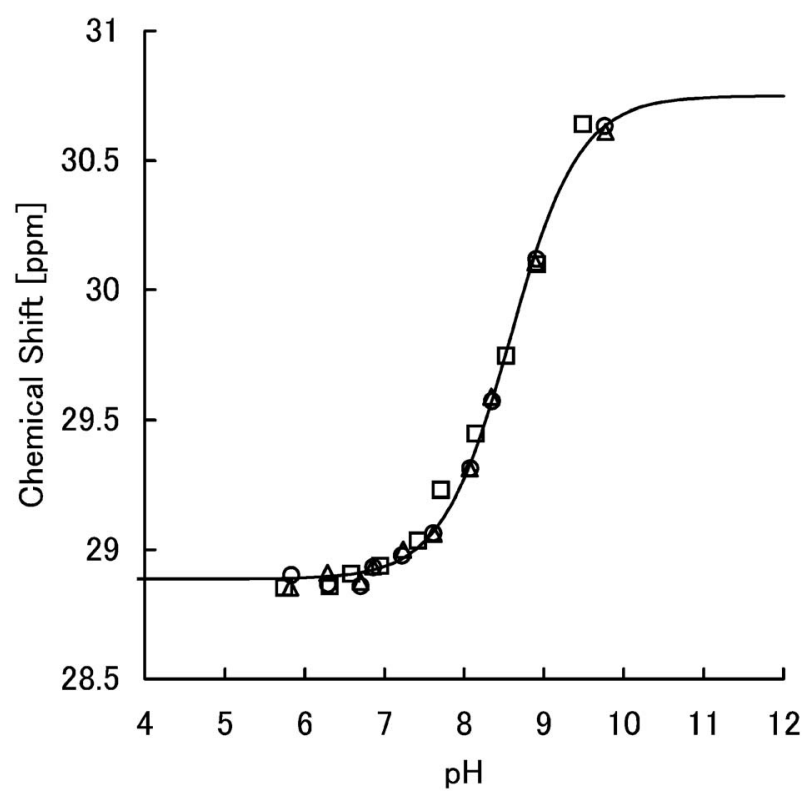

Fig. 16. ${ }^{13} \mathrm{C}$ NMR Titration Curve of ${ }^{13} \mathrm{C}-\mathrm{PZ}$

The solid line shows the theoretical curve calculate from the equation in the text using the obtained $\mathrm{p} K_{\mathrm{m}}, S_{\mathrm{c}}$ and $S_{\mathrm{n}}$ values. The symbols indicate the experimental values obtained with ${ }^{13} \mathrm{C}-\mathrm{PZ}$ concentrations of $200 \mu \mathrm{M}(\mathrm{O})$, $400 \mu \mathrm{M}(\square), 600 \mu \mathrm{M}(\Delta)$. 
予測されるよりも約 10 倍多いことになる。このこ とは，フェノチアジン系薬物が容易に PC 二重膜を 透過できることを説明している.

このように, リポソームと相互作用している各フ エノチアジン系薬物の $\mathrm{p} K_{\mathrm{a}}$ 值が約 1 低下したこと は, $N$-dimethyl 基が存在する $\mathrm{PC}$ 二重膜表面近傍 の誘電率が水相よりも低いことに起因すると考えら れた. ${ }^{28,29)}$

一方，コレステロールを $30 \%$ 含む PC リポソー ムを用いて同様の実験を行ったが， $\mathrm{p} K_{\mathrm{m}}$ 值は $\mathrm{PC}$ の みの場合とそれほど変化しない結果が得られた。 ${ }^{26)}$ このことは，PC二重膜の表面近傍の誘電率はコレ ステロールが含まれていても変らないことを示して いる.

NMR を用いた研究からフェノチアジン系薬物と $\mathrm{PC}$ 二重膜の相互作用についてこれまでに述べたよ うな詳細な知見が得られたが，試料溶液中に加えた フェノチアジン系薬物のどれくらいの割合が二重膜 と相互作用しているのか，すなわち PC二重膜中に 存在する CPZ の量については情報が得られていな い. そこで，前述した 2 次微分分光法による $\alpha$ - シ クロデキストリンとの結合定数の測定手法をリポ ソームに拡張することを考えた。

\section{3-2. 微分分光法による研究}

3-2-1. 2 次微分分光法による薬物のリポソームー 水系分配係数の測定法の開発薬物と生体膜との 親和性を評価する指標に $n$-octanol/水系における分 配係数から得られる $\log \mathrm{P}$ 值が広く用いられている. $\log \mathrm{P}$ 值は電荷を持たない中性の薬物に対してはよ い指標であるが，pH 7.4 付近でイオン化している ような薬物に対しては，生体膜と同じ基本構造を持 つ PCリポソームに対する薬物の分配係数の方が相 関性が高いと考えられている. ${ }^{30,31)}$ また，リポソー ムを生体膜モデルとしてではなく, DDS 担体とし て用いる場合にも，リポソームに対する薬物の分配 係数は脂質層にどれ位の薬物が含有されるかを示す 重要な值である。

リポソームに対する薬物の分配係数の測定には, バルク水相中若しくはリポソーム二重膜中のいずれ かの薬物濃度を測定する必要がある。このため一般 に超遠心分離や平衡透析などの分離手段が取られて いる．しかしながら，前者は水相に脂質成分が残る ことや，操作中に平衡が保たれているかどうかに疑
念が残る場合もあり，また後者は長時間を要し，か つ分離膜への薬物の吸着が問題となることがある.

これに対し，薬物の吸収スペクトルに水相と油相 （リポソーム二重膜中）とで差がある場合（メタク ロマジー現象)，リポソーム量とそれに依存したス ペクトルの変化量（ある波長における吸光度）の関 係から分配係数を求めることができる.32)この場 合，吸光度の測定波長において，リポソームによる 光吸収や光散乱の影響が完全に取り除かれているこ とが前提である.しかしながらリポソームによる光 散乱は極めて大きく，対照溶液による光散乱の完全 な相殺は困難な場合が多い。

Figure 17 (a) は CPZ の緩衝液にリポソーム（PC SUV) を順次添加したときの紫外吸収スペクトル である. ${ }^{33)}$ 試料溶液, 対照溶液両方に同量の PC SUV を添加したにも係わらず，上述のようにリポ ソームの強い光散乱のため完全な相殺が達成されて おらず，ベースラインが若干上下しており，したが って等吸収点も観測されない。これに対し，Fig. 17 (b) に示した 2 次微分スペクトルでは，明確な等 微分強度点（derivative isosbestic point）が 3 個観 測され，ベースラインの影響が完全に取り除かれて いることを示している. ${ }^{33)}$

なお，1990 年にパソコンの通信プロトコルであ る RS-232C を用いてデジタルスペクトルデータを パソコンに転送するシステムを構築したので，以後 は吸収スペクトルデータのパソコンへの取得はこの システムを用いて行った. ${ }^{33)}$

以上から，2 次微分スペクトルを用いればリポ ソームに起因するバックグランドシグナルの影響を 完全に消去でき，薬物のリポソーム／水系での分配 係数を求めることは可能になると考え，以下の理論 を展開した。

分配係数は次式で定義されるモル分配係数 $\left(K_{p}\right)$ を用いた. ${ }^{32,33)}$

$$
K_{p}=\frac{\left(\left[P_{m}\right] /\left[P_{t}\right]\right) /[L]}{\left(\left[P_{w}\right] /\left[P_{t}\right]\right) /[W]}
$$

ここで, $\left[P_{m}\right]$ と $\left[P_{w}\right]$ はそれぞれ脂質相及び氷相中 に存在する薬物のモル濃度であり, $\left[P_{t}\right]$ は全薬物濃 度， $[L]$ と $[W]$ はそれぞれ脂質と水 $\left(37^{\circ} \mathrm{C}\right.$ で 55.3 M）のモル濃度である.

ある波長における薬物のリポソーム添加前の微分 值と添加後の微分值の差を $\Delta D$ とし, $E_{m}$ 及び $E_{w}$ 

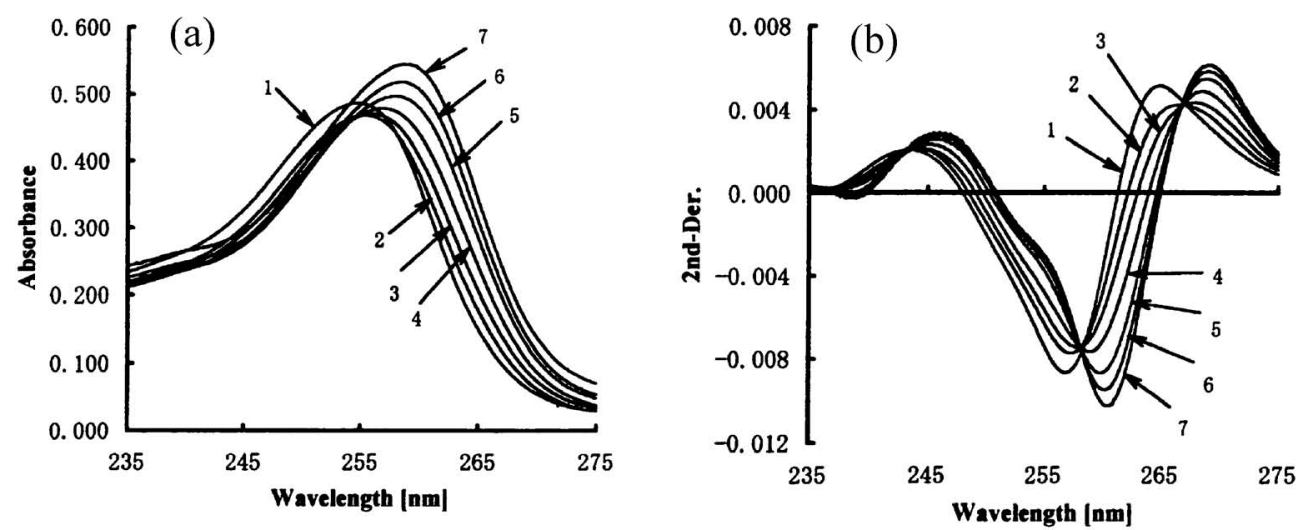

Fig. 17. Absorption (a) and Second-derivative (b) Spectra of $15 \mu \mathrm{M}$ Chlorpromazine in a HEPES Buffer Solution Containing Several Amounts of PC SUV

PC concentration: $1-7 ; 0-1.43 \mathrm{~mm}$.

を脂質相及び水相中の薬物のモル微分強度, さらに その差を $E=E_{m}-E_{w}$ とすると, $\Delta D$ は $\Delta D=E$ $\left[P_{m}\right]$ と表わされる. ${ }^{33)}$ すなわち, $\Delta D$ 值はリポソー ム中の薬物の濃度に比例することを示している。こ れらの式から， $\Delta D$ は $K_{p}$ を用いて次のように表す ことができる. ${ }^{33)}$

$$
\Delta D=\frac{K_{p} \Delta D_{\max }[L]}{[W]+K_{p}[L]}
$$

ここで, $\Delta D_{\max }$ は溶液中の薬物分子のすべてがリポ ソームに分配されたとした場合の $\Delta D$ 值である.

したがって，種々の $[L]$ に対する $\Delta D$ 值を測定すれ ば，上式から $\Delta D_{\max }$ 及び $K_{p}$ を求めることができる.

$K_{p}$ 值は，上式に非線形最小二乗法を適用した BASIC 言語（のちに Visual BASIC へ改作）によるプ ログラムを作成して計算した. ${ }^{33)}$

以上のようにして，リポソーム (PC SUV)-水系 の $\mathrm{CPZ}, \mathrm{PZ}$ のモル分配係数を相対標準偏差 $10 \%$ 以 下 $(n=6)$ の精度で求めることができた. ${ }^{33)}$

3-2-2. リポソームの粒子径と分配係数の関連 ${ }^{34)}$ 上述のように， 2 次微分分光法を用いてリポソーム (PC SUV) に対するフェノチアジン系薬物の分配 係数を測定したが，リポソームは粒子径が 20-500 $\mathrm{nm}$ 以上まで各種の大きさのものが調製可能であ り，目的により使い分けることができる，その中 で，超音波処理によって作製される SUV は粒子径 が約 $20 \mathrm{~nm}$ と小さいため, 内側と外側の PC 分子 数が約 $2: 1$ と異なり, また，パッキング状態は内 側の方が密であることが知られている，一方，粒子 径が大きい場合は内側と外側の PC 分子数にほとん ど差はなく，パッキング状態も同じである，以上か
ら，リポソームの粒子径により分配係数が異なる可 能性があるが，検証されてはいなかった。 そこで, 20-600 nm の各種の大きさのリポソームを調製し, 2 次微分分光法を用いて CPZ 及び TFZ のそれぞれ の大きさのリポソームに対する分配係数を測定し， 比較検討した. ${ }^{34)}$

リポソームによる光散乱は粒子径の増加に伴って 強くなる. Figure 18 (a) は粒子径が $400 \mathrm{~nm}$ のリポ ソームの実験例であるが，バックグランドシグナル の相殺が取れておらず，ベースラインが大きくずれ ていることが明らかで，等吸収点も当然ながら全く みられない。これに対し，Fig. 18(b)に示した2次 微分スペクトルでは 3 個の等微分強度点が観測さ れ，このように吸収スペクトルにバックグランドの 影響が強く残っている場合でも，2次微分すること により完全にその影響が消去されることが分かる.

そこで，20-600 nm の各種の大きさのリポソーム に対する CPZ, TFZ の分配係数を 2 次微分スペク トルを用いて求めたところ，いずれの薬物について も分配係数はリポソーム粒子径による差を示さず, フェノチアジン系薬物とリポソーム $\mathrm{PC}$ 二重膜との 相互作用はリポソームの大きさに係わらず，分配で 扱えることが証明された。 ${ }^{34)}$ 同様にして，粒子径の 大きい赤血球ゴースト膜にも 2 次微分分光法は応用 できた. ${ }^{35)}$

3-2-3. 熱力学的検討 次に, $\mathrm{CPZ}, \mathrm{PZ}, \mathrm{TFZ}$ に加えて側鎖に pyperazine 核を有する trifluoperazine (TFPZ) の 4 種のフェノチアジン系薬物を用 いて，フェノチアジン系薬物とリポソームの PC二 重膜との相互作用について熱力学的検討を行った. 

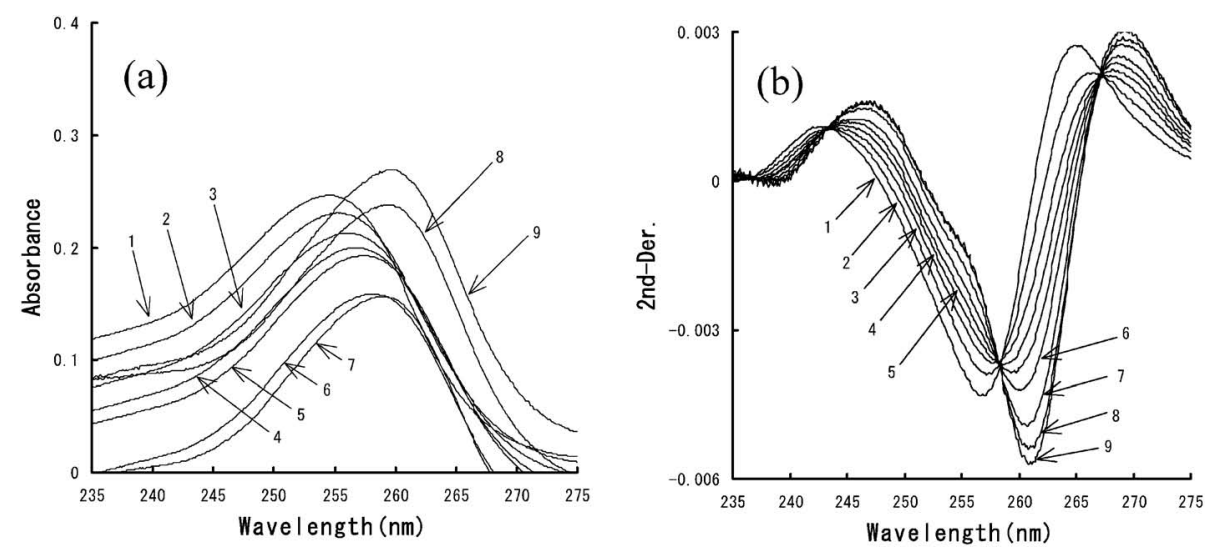

Fig. 18. Absorption (a) and Second-derivative (b) Spectra of CPZ in the Presence of Several Amounts of PC LUV of $400 \mathrm{~nm}$ Diameter

PC concentrations (mM): 1-9; 0-1.16.

すなわち, 2 次微分分光法を用いて $10-40^{\circ} \mathrm{C}$ の 4 の温度で, これらの薬物の PC リポソームに対する 分配係数を測定し，Van’t Hoff plot からそれぞれ の熱力学的パラメーターを求めた. ${ }^{36)}$

得られた熱力学的パラメーターからフェノチアジ ン系薬物の $\mathrm{PC}$ 二重膜への分配機構に関する有用な 情報が得られた。すなわち，各薬物の $\Delta H_{\mathrm{w} \rightarrow 1}$ はい ずれも負の值を示し, フェノチアジン系薬物の PC リポソームへの分配は静電的相互作用も寄与してい ること, また, $\Delta H_{\mathrm{w} \rightarrow 1}$ の大きさ（絶対值）の順位 から, 静電的相互作用の寄与の大きさは $\mathrm{PZ}>\mathrm{CPZ}$ $>\mathrm{TFZ}>\mathrm{TFPZ}$ であることが分かった。一方, $\Delta S_{\mathrm{w} \rightarrow 1}$ 值が正であることから, 薬物が PC二重膜に 分配した結果，フェノチアジン環の侵入が PC二重 膜のアシル鎖領域の運動を乱していることが示唆さ れる。すなわち， $\Delta S_{\mathrm{w} \rightarrow 1}$ 值の序列 TFPZ $\geq \mathrm{TFZ}>$ $\mathrm{CPZ} \gg \mathrm{PZ}$ はフェノチアジン環の C-2 位の置換基の 大きさ $\left(\mathrm{CF}_{3}>\mathrm{Cl}>\mathrm{H}\right)$, つまり, 環全体の大きさに 依存していることが示された. ${ }^{36)}$

3-2-4. フェノチアジン系薬物の活性代謝物の分 配係数 CPZの主要活性代謝物である $N$ monodemethylated chlorpromazine (Nor1-CPZ)の 血漿中での濃度は元の CPZ の約 $17 \%$ 程度である が, 37) 他の代謝物よりも脳内に高濃度に蓄積される

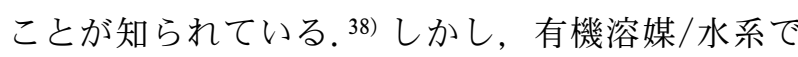
測定された分配係数は CPZ に較べて極めて小さ く, 生体膜への親和性が低いことになり, 脳内蓄積 性が説明できない。そこで, (Nor1-CPZ, Nor1-PZ, Nor1-TFZ) を合成し, 27) その PC リポソームへの
分配係数を 2 次微分分光法を用いて測定した. その 結果, PCリポソームに対して測定された值はいず れも, 元のフェノチアジン系薬物とほぼ同等で, 脳 への移行が可能であることが支持され, リポソーム／ 水系の分配係数が薬物の生体膜への親和性の指標之 して従来の有機溶媒／水系の分配係数よりも適切で あることが実証された. ${ }^{39)}$

\section{3-2-5. ベンゾヂアゼピン系薬物の分配係数} 次に, 微分分光法がリポソーム/水における薬物分 配係数の測定に広く適用可能であることを検証する ため, ベンゾヂアゼピン系薬物への適用を行った.

Figure 19(a) は diazepam のバッファー溶液に PC SUV を順次添加したときの吸収スペクトルである が，PC SUV に起因するバックグランドシグナルの 相殺は不十分で等吸収点はみられず, さらに, PC SUV 添加によるスペクトルの変化も小さく, 吸収 スペクトルから分配係数を計算するデー夕は得られ ない.しかし, Fig. 19(b)に示した 2 次微分スペク トルでは 3 個の等微分強度点が現れ, また, スペク トル変化が増幅されており, 正確に $\Delta D$ 值を読み 取ることが可能となっている. 以上から， 2 次微分 分光法により diazepam, flurazepam の PCリポソー ムへの分配係数を相対標準偏差 $10 \%$ 以内 $(n=5)$ と精度よく決定できた. ${ }^{40)}$

3-2-6. ステロイド系薬物の分配係数 ${ }^{41)}$ ステ ロイド系薬物の PC リポソーム/水系の分配係数も 2 次微分分光法を適用することによって測定するこ とが可能となった. Figure 20 (a) は dexamethasone の例であるが, リポソームによるバックグランドシ 

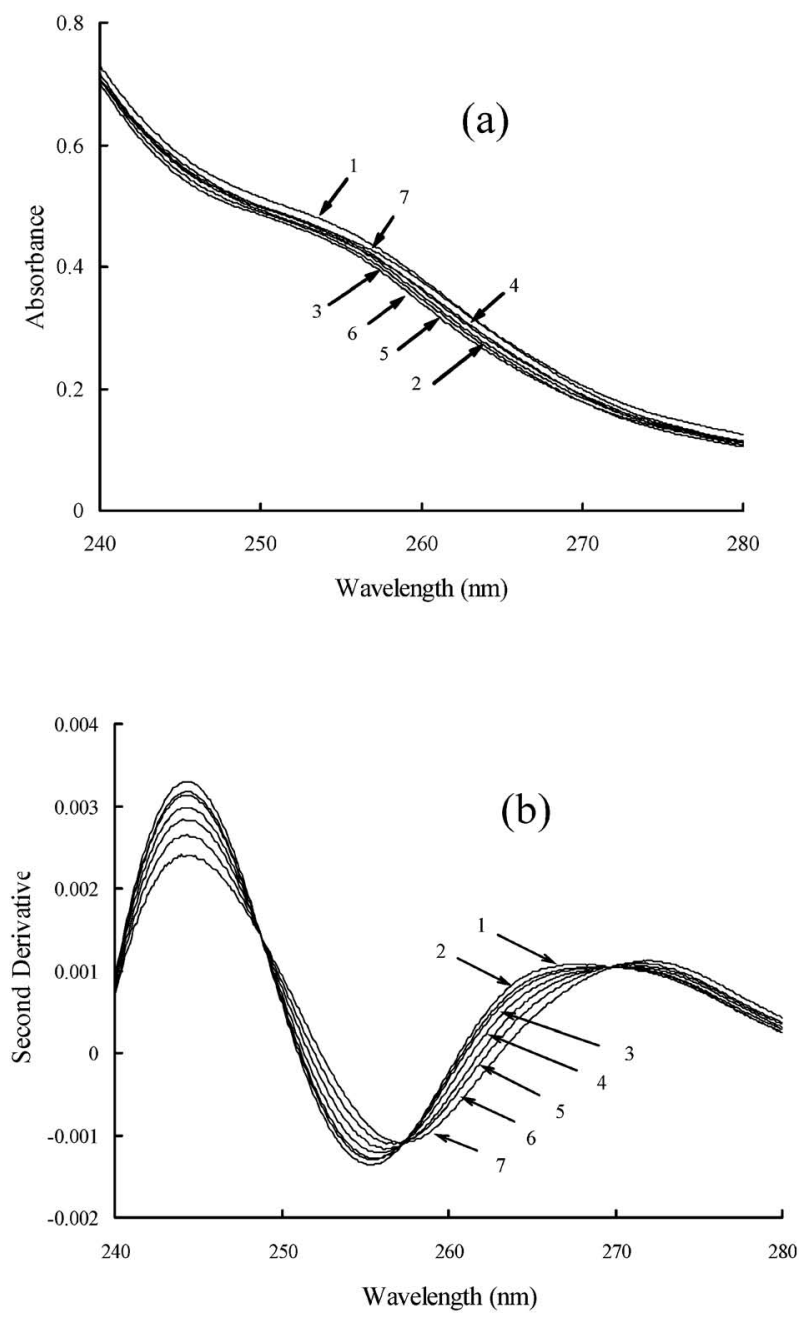

Fig. 19. Absorption (a) and Second-Derivative (b) Spectra of $30 \mu \mathrm{m}$ Diazepam in a HEPES Buffer Solution Containing Several Amounts of PC SUV

PC concentrations: 1-7;0-1.42 mM.
グナルの影響により等吸収点がみられず，また PC リポソーム添加によるスペクトル変化も小さい。こ れに対し，Fig. 20(b)に示す2 次微分スペクトルで は，ベースラインが補正されて 3 個の等微分強度点 が現れ，さらに，スペクトル変化が増幅されて変化 量を精度よく読み取ることが可能であり，これより 分配係数を相対標準偏差 $10 \%$ 以内と精度よく求め ることができた. ${ }^{41}$

同様にして，6種類のステロイド系薬物について PC リポソームに対する分配係数を求めることがで きたので，分配係数とステロイド系薬物の化学構造 の関連を検証した。 また，オクタノール／水系の分 配係数 ${ }^{42)}$ の大さと臨床的薬効の序列とは一致しな かったが，得られたリポソーム／水系での分配係数 は臨床的薬効の序列と一致し, リポソーム/水系で の分配係数が薬物の lipophilicity の指標として適切 であることを示すことができた. ${ }^{41}$

\section{3-2-7. リポソーム脂質組成の薬物分配係数に及} ぼす影響の検討実際の生体膜は PC 以外に phosphatidylserine (PS) や phosphatidylethanolamine（PE）等のリン脂質及び cholesterol を含んで いる，したがって，生体膜の脂質組成の違いによる 薬物への親和性の差が生じることが考えられ，その ことが薬物の生体内分布の要因の 1 つであると考え られる。

そこで，まず cholesterol 含量がフェノチアジン 系薬物の分配係数に及ぼす影響を検討した。すなわ

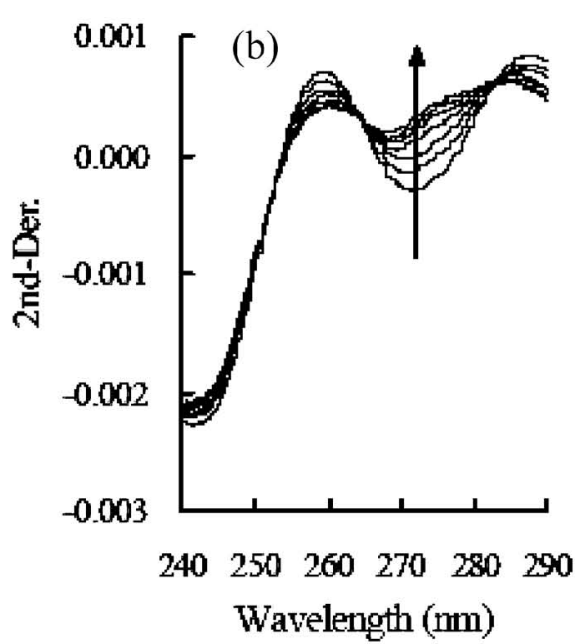

Fig. 20. Absorption (a) and Second-derivative (b) Spectra of $40 \mu \mathrm{M}$ Dexamethasone in Hepes Buffer (pH 7.4, 37 (C) Varying Concentration of PC SUV

PC concentrations: $0.0-2.4 \mathrm{~mm}$ (in the direction of the arrow). 
ち cholesterol を 0-30\%含むPC SUV を作製し，そ れらに対する CPZ, TFZ の分配係数を 2 次微分分 光法によって求めた。 その結果, cholesterol の含量 依存的に分配係数は減少し，30\% cholesterol では $\mathrm{CPZ} ， \mathrm{TFZ}$ ともに PC のみの場合の約 $50 \%$ となる ことが示された. ${ }^{34)}$

次に，PS 又は PEを含んだ PC SUV を作製し， それらに対するフェノチアジン系薬物（CPZ， TFZ）の分配係数を 2 次微分分光法を用いて測定し た. ${ }^{43)}$ Figure 21 はその結果である。すなわち，PS あるいは PE を含む PCリポソームに対する $\mathrm{CPZ}$ 及び TFZの分配係数を，PCのみの場合の分配係 数に対する相対值で表し，PS あるいはPEの含量 についてプロットした。 PE を添加しても CPZ, TFZ 両薬物とも分配係数はほとんど変化しないが, PS の場合はPS 含量に依存して両薬物とも分配係 数が増加し，PS 含量が $30 \%$ におてはPCのみの リポソームに比して 2-3 倍も大きくなっている。こ のことは, pH 7.4 において中性である PE はフェ ノチアジン系薬物に対する親和性は PC と変らない が，酸性リン脂質として荷電しているPS は PCに 較べて親和性がはるかに大きいことによると考えら れる. ${ }^{43)} こ の$ 結果は, 前述の熱力学的検討において 得られた，フェノチアジン系薬物の PC 二重膜への 分配には，静電的相互作用の寄与も含まれていると いう結果 ${ }^{36)}$ とよく符合している.

同様にして，ベンゾジアゼピン系薬物, diazepam, flurazepam の分配係数に対するPS の影響を調 ベたところ，30\%のPS を含むPCリポソームでは，

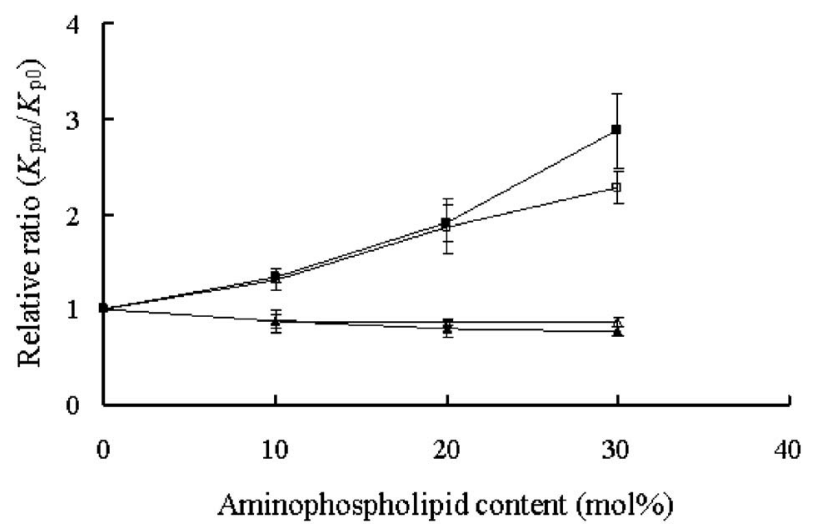

Fig. 21. Relative Partition Coefficients of TFZ (closed) and CPZ (open) at Several PS (square) and PE (triangle) Contents
PC のみの場合に較べて, diazepam で約 1.4 倍, flurazepam では約 4.8 倍を示した. flurazepam の $\mathrm{p} K_{\mathrm{a}}$ は 8.1 であるので, $\mathrm{pH} 7.4$ の試料溶液では 80 \%以上がカチオン型であり，フェノチアジン系薬物 の場合と同様，PS によりリポソーム表面が負電荷 を有するため親和性が高くなったと考えられる. ${ }^{44)}$

以上の結果は，PSが多く含まれている神経細胞 や脳にフェノチアジン系薬物やベンゾジアゼピン系 薬物等の向精神薬が分布することの要因と考えら れ，生体膜の脂質組成が薬物の生体内分布に大きく 寄与していることを示唆している.

\section{4. 微分分光法及び NMR 法による薬物-血清ア} ルブミンの相互作用の解明研究

薬物のリポソームすなわちリン脂質二重膜に対す る分配係数は薬物の吸収や組織への移行，分布に関 連する定量的指標であるが，一方，生体内の薬物の 輸送や有効血中濃度に大きく関与するのは血清アル ブミンへの結合である.

血清アルブミンは血中に約 $0.6 \mathrm{~mm}$ と最も多く存 在し，血漿タンパク質の約 $60 \%$ を占めている，血 清アルブミンは血液の膠質浸透圧維持のほか, 脂肪 酸，ビリルビン，種々のイオンなどの内因性物質に 加えて, 薬物に代表される種々の外因性物質も可逆 的に結合し，血中でこれらの物質を運搬する. ${ }^{45)}$

血中において結合型薬物は血管壁を通過できず, 非結合型薬物だけが血中から組織に移行して作用部 位に到達すると考えられており，薬物の血清アルブ ミンへの結合は薬理効果や副作用の発現，体内動態 に大きな影響を及ぼす。

4-1. 微分分光法による研究薬物一血清アル ブミン結合定数の測定は，一般に，限外ろ過あるい は平衡透析等の分離手段を用いて得た水相中の非結 合薬物濃度を測定し求められている。前者はろ過膜 への吸着や平衡状態を乱す懸念があり，後者は同じ く透析膜への吸着と測定に長時間を要するといつた 欠点がある。これに対し，アルブミンに結合するこ とによって薬物の吸収スペクトルに変化が生じる場 合（メタクロマジー）には，アルブミン自体による 光吸収を対照溶液により相殺できれば，吸光度の変 化から結合定数を求めることができる。しかし，ア ルブミンによるバックグランドシグナルは強く，そ の影響を完全に相殺することは困難である.

そこで，筆者はリポソームの場合と同様に 2 次微 
分分光法を適用して，アルブミンのバックグランド シグナルの影響によるベースラインの不一致を除去 し，分離手段を用いることなく平衡を保ったままの 状態で薬物ーアルブミン結合定数を求める手法を開 発した.

4-1-1. 2 次微分分光法によるウシ血清アルブミ ン（BSA）と CPZ 及び TFZ との結合定数の測定 ${ }^{46)}$ Figure $22(\mathrm{a})$ に種々の濃度の BSA を含む緩衝溶液 中の TFZ の紫外吸収スペクトルを示したが，対照 溶液は試料溶液と同濃度のBSA を含んでいるのに 係わらず，BSA によるバックグランドシグナルが 極めて強いため完全に相殺されず，平衡系に現れる べき等吸収点がみられない。これに対し 2 次微分処 理を行った Fig. $22(\mathrm{~b})$ では，2 個の等微分強度点が 観測され，バックグランドシグナルの影響が完全に 消去されていることが分かる，そこで，薬物とアル ブミンの結合について，以下の理論の展開を行つた.

薬物とアルブミンを含む試料溶液のある波長にお ける微分值 $D$ と薬物のみの微分值の差を $\Delta D$ とす ると, $\Delta D$ は結合型薬物濃度, $C_{\mathrm{b}}$ に比例し, $\Delta D=$ $E\left[C_{\mathrm{b}}\right]$ と表すことができる. ここで $E=E_{\mathrm{b}}-E_{\mathrm{u}}$ で, $E_{\mathrm{b}} ， E_{\mathrm{u}}$ はそれぞれ結合型，非結合型の薬物のモル 微分強度を示す。試料溶液中に存在する全薬物分子 （濃度を $C_{\mathrm{t}}$ とする）がアルブミンに結合したときの $\Delta D$ 值を $\Delta D_{\max }$ とすると, $\Delta D_{\max }=E\left[C_{\mathrm{t}}\right]$ と表せ， 薬物のアルブミンに対する結合割合 $\alpha$ は $\alpha=\Delta D /$ $\Delta D_{\max }$ で与えられる. ${ }^{46)} \Delta D_{\max }$ 值は， $\Delta D$ と全アル ブミン濃度 $[P]$ との両逆数プロットを行い, 全ア ルブミン濃度を無限大に外挿することにより求める ことができるから， $\Delta D$ 值から $\alpha$ が得られる.

以上から, 結合型, 非結合型薬物濃度 $\alpha\left[C_{\mathrm{t}}\right], \quad(1-$ $\alpha)\left[C_{\mathrm{t}}\right]$ ，及びアルブミン 1 分子当たりに結合して いる薬物の分子数 $r=\alpha\left[C_{\mathrm{t}}\right] /[P]$ を用いて, Scatchard plot による解析を行うことができる。

上述の理論に従って, CPZ, TFZ のいくつかの濃 度について Scatchard plotを行い，Fig. 23 を得 た。 各プロットは横軸に対して平行な直線を示して おり，CPZ，TFZ と BSA の相互作用は分配型の非 特異的結合モデルを適用できることが分かった. ${ }^{46)}$

薬物とアルブミンの相互作用が非特異的結合モデ ルにより説明される場合，結合定数 $K\left(\mathrm{M}^{-1}\right)$ は次 式で表すことができる.
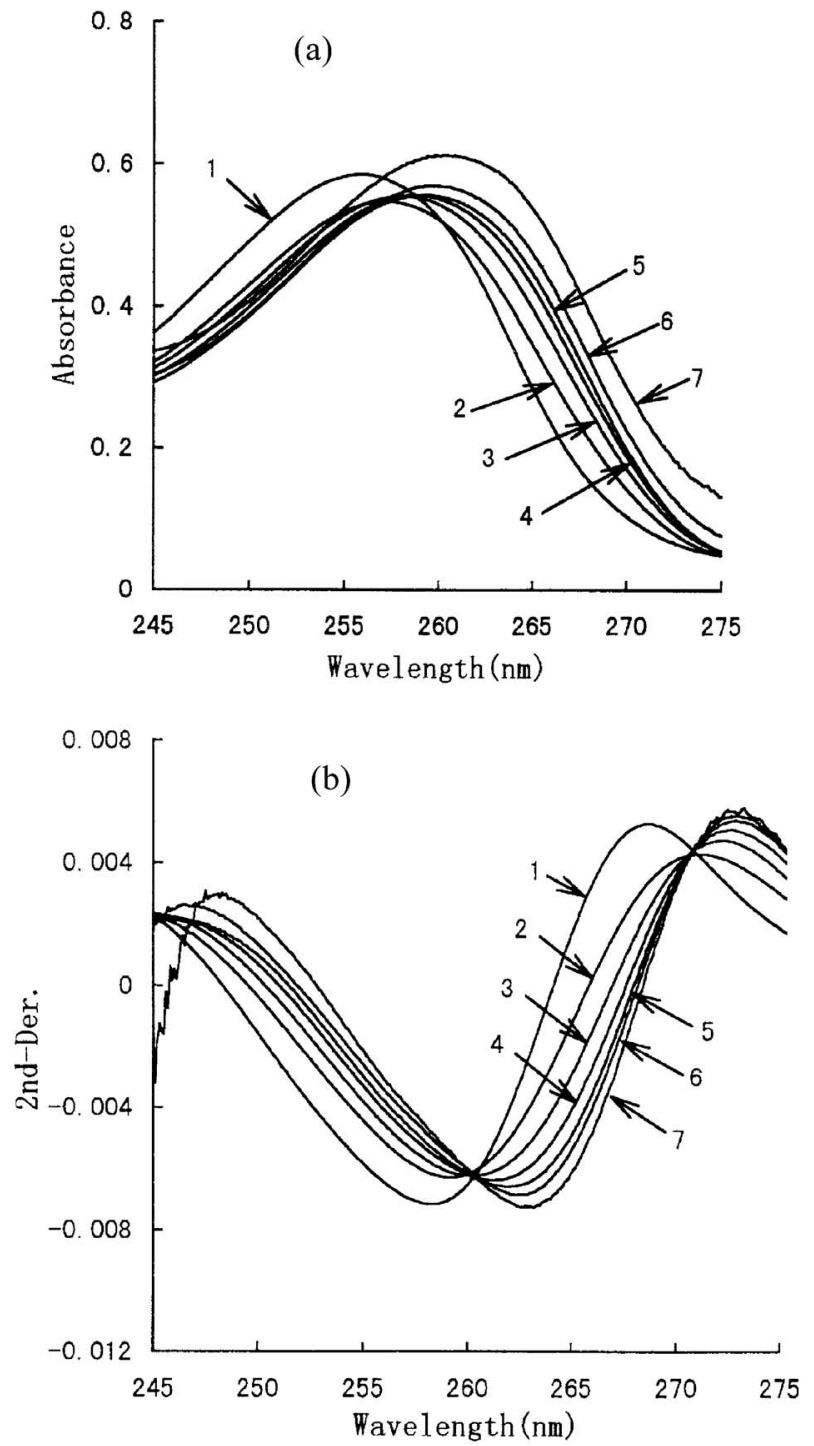

Fig. 22. Absorption (a) and Second Derivative (b) Spectra of $20 \mu \mathrm{M}$ TFZ in a Phosphate Buffer Solution (pH 7.4, 37 (C) Containing Various Amounts of BSA BSA concentration $(\mu \mathrm{M})$ : $(1)-(7) ; 0.0-70.0$.

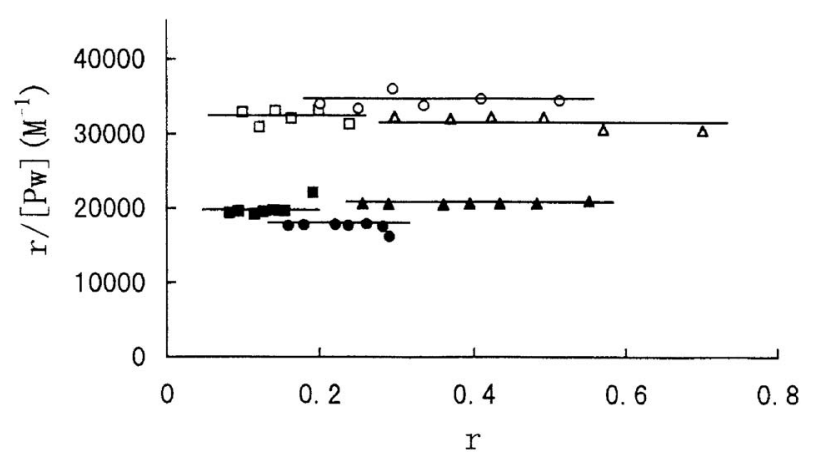

Fig. 23. Scatchard Plot for the Interaction of $\mathrm{CPZ}$ and $\mathrm{TFZ}$ with BSA, Respectively

CPZ concentration $(\mu \mathrm{M}): 10(\mathbf{\square}), 20(\bullet), 30(\mathbf{\Lambda})$, TFZ concentration $(\mu \mathrm{M}): 10(\square), 20(\bigcirc), 30(\Delta)$. 


$$
\frac{r}{\left[C_{\mathrm{u}}\right]}=\frac{\left[C_{\mathrm{b}}\right]}{[P]\left[C_{\mathrm{u}}\right]}=K
$$

上式を $\Delta D, \Delta D_{\max }$ を用いて表し， $\Delta D$ について整 理すると, 次式が得られる。

$$
\Delta D=\frac{K[P] \Delta D_{\max }}{(1+K[P])}
$$

上式に Taylor 展開併用最小二乗法を適用した Visual Basic によるプログラムを作製し，最適な $K$ 及び $\Delta D_{\max }$ を算出した.

10-30 $\mu \mathrm{M}$ の種々の濃度の CPZ，TFZ について測 定実験を行い，相対標準偏差 $10 \%$ 以内で精度よく 結合定数を求めることができた。 また，得られた各 $K$ 值は薬物濃度に依存せずそれぞれ一定の值を示し，

BSA に対する CPZ, TFZ の結合が分配型の非特異 的結合モデルで扱えることが確認された. ${ }^{46)}$

\section{4-1-2. BSA と CPZ 及び TFZ との結合に対する} 無機イオンの影響の解明＼cjkstart血中には種々の無機イ オンが存在し，その中でも $\mathrm{Na}^{+}, \mathrm{Cl}^{-}$は，それぞ れ約 $0.15 \mathrm{M}, 0.1 \mathrm{M}$ と高濃度で存在しているが, そ れらが薬物ーアルブミン結合に及ぼす影響について の定量的な知見はない. そこで, 筆者は各種の無機 塩を種々の濃度で含む場合の CPZ, TFZの BSA への結合定数 $(K)$ を 2 次微分分光法を用いて測定 し, $\mathrm{Na}^{+}, \mathrm{K}^{+}, \mathrm{Cl}^{-}, \mathrm{Br}^{-}, \mathrm{I}^{-}, \mathrm{SO}_{4}^{2-}$ の影響を検討し た. Figure 24(a)，(b) はこれらの無機塩が存在しな いときの $K$ 值に対する無機塩存在時の $K$ 值の比 を，無機塩濃度についてプロットしたものであ る. ${ }^{47)}$

まず， $\mathrm{Na}_{2} \mathrm{SO}_{4}$ が $\mathrm{CPZ}, \mathrm{TFZ}$ の結合定数になんら 影響を及ぼしていないことから, $\mathrm{Na}^{+}$及び $\mathrm{SO}_{4}{ }^{2-}$ はフェノチアジン系薬物の BSA 結合に影響しない ことが明白である。また， Na 塩（Fig. 24(a)）と $K$ 塩 (Fig. 24(b)) ですべての塩について差が認め られないことから $\mathrm{K}^{+}$もフェノチアジン系薬物の結 合に影響しないことが分かる。一方, $\mathrm{Cl}^{-}, \mathrm{Br}^{-}, \mathrm{I}^{-}$ についてはいずれも濃度依存的に結合定数を低下さ せ，その度合は $\mathrm{I}^{-} \gg \mathrm{Br}^{-}>\mathrm{Cl}^{-}$の順であることが明 らかとなった。 また， $\mathrm{Cl}^{-}$はその生理的濃度である $0.1 \mathrm{M}$ 近傍で影響が一定に近づくことは興味深い.

フェノチアジン系薬物は pH 7.4 ではほとんどが プロトン化された陽イオンであり, これらの陰イオ ンによって BSA との結合が阻害されることは, フ エノチアジン系薬物とBSAの相互作用に対して静
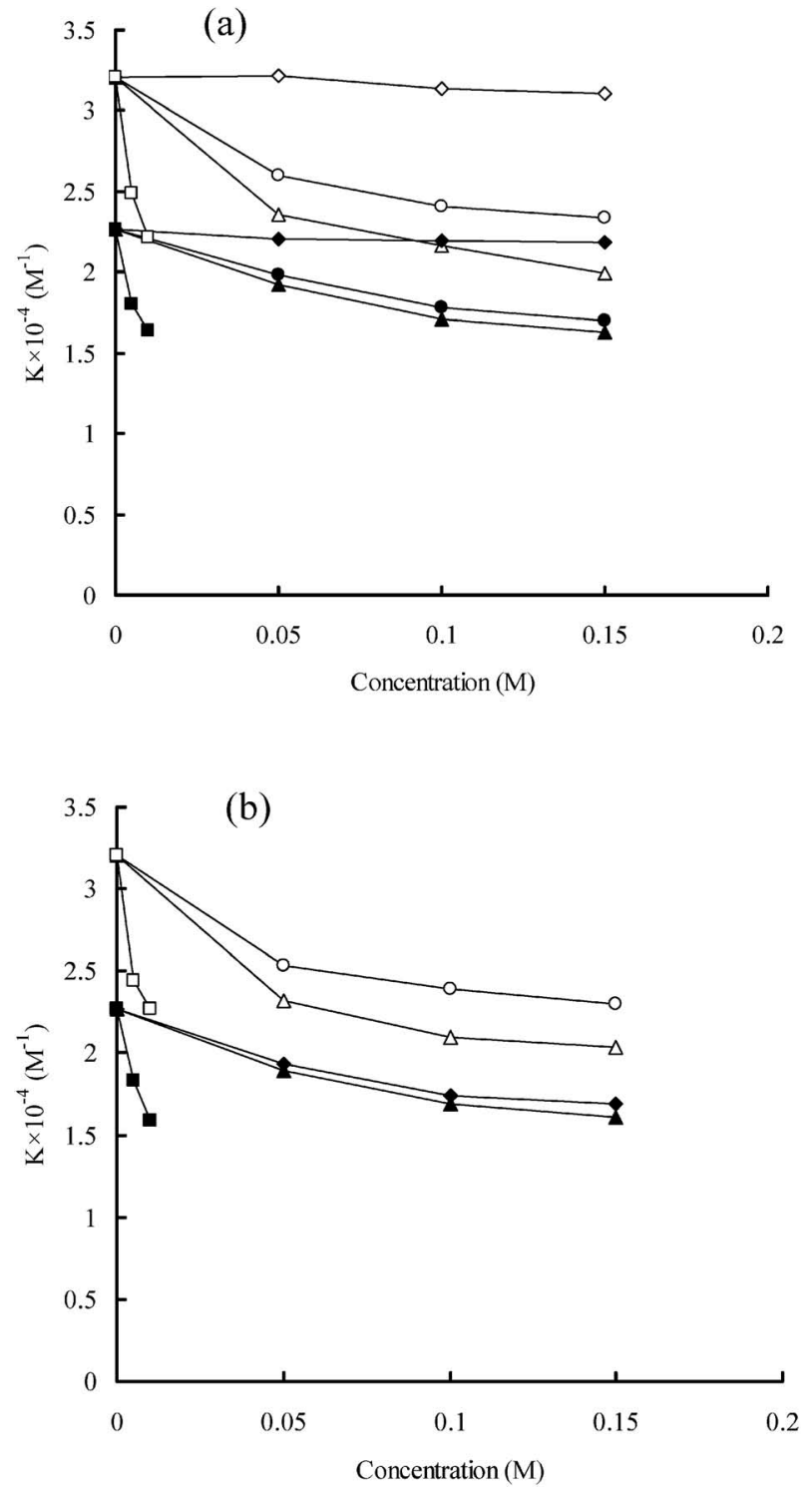

Fig. 24. Effect of Sodium (a) and Potassium (b) Salts on the Binding Constants of TFZ (Open Symbols) and CPZ (Closed Symbols) to BSA at $37^{\circ} \mathrm{C}$ and $\mathrm{pH} 7.4$

(a): The sodium salts added, $(\diamond): \mathrm{Na}_{2} \mathrm{SO}_{4},(O): \mathrm{NaCl},(\triangle): \mathrm{NaBr}$, $(\square)$ : NaI, (b): The potassium salts added, $(O): \mathrm{KCl},(\triangle): \mathrm{KBr},(\square): \mathrm{KI}$.

電的な寄与は小さいと考えられた.

一方，これらの陰イオンによる結合阻害の序列が これらの陰イオンのイオン半径の序列と同一である ことから，これらの陰イオンが BSA に結合するこ とにより，フェノチアジン系薬物に対する BSAの 結合部位が影響を受けると考えられた. ${ }^{47)}$

上記の結果より，薬物のアルブミンへの結合を考 察する際には，血中に $0.1 \mathrm{M}$ 存在する $\mathrm{Cl}^{-}$の影響を 考慮に入れることが重要であることが示された。

4-2. ${ }^{19}$ F NMRによる研究薬物ーアルブミン 
結合の結合定数は有効血中薬物濃度すなわち血中の 非結合薬物濃度を見積もるために必要不可欠な数值 である。しかし，薬物ーアルブミン結合は上述の無 機イオンのみならず，その他の様々な内因性物質に よって影響を受ける可能性がある。また，他の薬物 を同時投与した場合に置換現象により予測しない高 い血中薬物濃度を生じる可能性もある。したがつ て，内因性，外因性物質による結合の競合や結合部 位に関するより詳細な解明が必要である.

ヒト血清アルブミン（HSA）の結晶状態におけ る 3 次元構造は 1992 年 ${ }^{48)}$ に He と Carter によって $\mathrm{X}$ 線構造解析により明らかにされた。彼らはまた 薬物が結合した HSA についても結晶構造を解析 し，薬物結合サイトがサブドメイン II A と III A で あることを示した。これらはそれぞれ従来の Sudrow の薬物結合サイトの Site I， Site II に対応 し，それぞれに分類されていた薬物と矛盾していな い. ${ }^{48)}$

一方, 溶液中での構造化学的な研究は NMR が最 適と考えられるが，アルブミンの分子量は $65 \mathrm{~K}$ と 大きく，測定試料として薬物とアルブミンのモル比 を $1 ： 1$, あるいはそれ以下に設定すると，薬物の ${ }^{1} \mathrm{H}$ NMR シグナルの強度はアルブミン由来のシグ ナルの方が圧倒的に大きく，さらに結合によるブ ロードニングのため観測は困難である。 ${ }^{13} \mathrm{C} \mathrm{NMR}$ においても，たとえ ${ }^{13} \mathrm{C}$ 標識した薬物を用いたとし てもアルブミン由来のシグナルとの重なり，及びブ ロードニング等で困難は変わらない。

そこで筆者は TFZ がフッ素原子を有しているこ とから ${ }^{19} \mathrm{~F}$ NMR に着目した。生体物質中にはフッ 素を含むものは見当たらないから，どのような生体 物質が共存しようとも薬物由来のシグナル以外に現 れるものはない。さらに， ${ }^{19} \mathrm{~F}$ 核は磁気モーメント の大きさが ${ }^{1} \mathrm{H}$ 核とほぼ同等の大きさを持ち，天然 存在比は $100 \%$ であるため相対的感度は ${ }^{1} \mathrm{H}$ 核に近 い高感度核種である。したがって，生体物質が共存 する系において， $\mu \mathrm{M}$ オーダーの薬物濃度でも信号 を得ることが可能である。また， ${ }^{19} \mathrm{~F}$ NMR の化学 シフトは $250 \mathrm{ppm}$ と極めて広く，わずかな環境変 化による化学シフトの変化を検出し易い. 以上のご とく ${ }^{19}$ F NMR は含フッ素薬物-生体マクロ分子の 相互作用の解明に多くの利点を有していると考えら れる。ファ素を含む薬物は，向精神薬，ニューキノ
ロン抗菌剤，ステロイド薬等に多くの種類があり， かつ重要なものが多く, ${ }^{19} \mathrm{~F} \mathrm{NMR}$ は生体物質との 相互作用の解明に広範囲の薬物に適用可能であると 考えられる。

4-2-1. TFZ と BSA, 及びヒト血清アルブミン （HSA）の相互作用の解明49) Figure 25 は 1.0 mM TFZ の buffer 溶液 (a)に $1.0 \mathrm{mM}$ の BSA (b) 及 び $1.0 \mathrm{mM}$ の HSA (c) を加えたときの ${ }^{19}$ F NMR ス ペクトルである. (a) の buffer のみでは TFZ の $\mathrm{CF}_{3}$ は 1 本の鋭いシグナルを示すが，BSA（b)あるいは $\mathrm{HSA}(\mathrm{c})$ が存在すると, 元の位置から $0.2 \mathrm{ppm}$ 低磁 場側と $0.7 \mathrm{ppm}$ 高磁場側へシフトしたブロードな 2 本のシグナルに分裂して現れている。すなわち， TFZ は BSA，HSA のいずれに対しても，少なくと も 2 カ所のサイトで結合していることが示された. また，高磁場側と低磁場側のシグナルの強度比は BSA と HSA では逆転しており，TFZ の各サイト への分布が BSA と HSA で異なることが明らかで ある. ${ }^{49}$

次に，結合サイト既知のリガンドを用いて競合実 験を行い，サイトの同定を試み，測定結果をまとめ て Fig. 26 に示した.

Site I リガンドである warfarin を加えた場合, BSA（Fig. 26A(b))，HSA(Fig. 26B(b)) のいずれ についても添加前（Fig. 26A (a)，B (a)）とスペク トルに変化はみられず，TFZ は Site I には結合し ていないことが明らかである。

続いて， SiteIIリガンドである L-tryptophan を添 加した結果が Fig. 26A(c)，B (c)で， BSA，HSAの

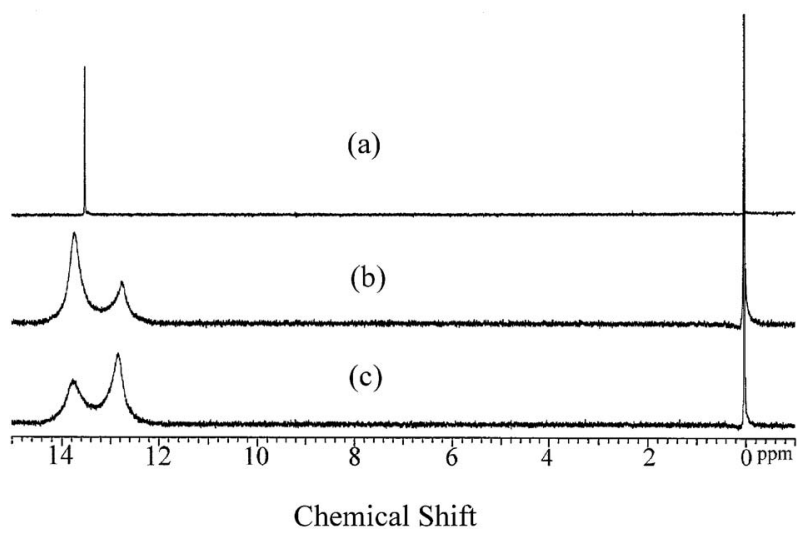

Fig. 25. ${ }^{19} \mathrm{~F}$ NMR Spectra of $1.0 \mathrm{mM}$ TFZ in Buffer (a) without Serum Albumin, (b) with $1.0 \mathrm{~mm}$ BSA, (c) with 1.0 mM HSA 
A (BSA)

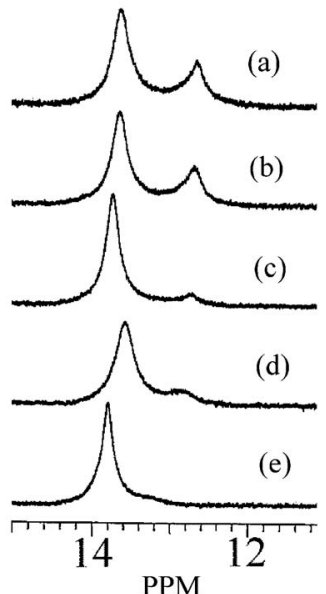

B (HSA)

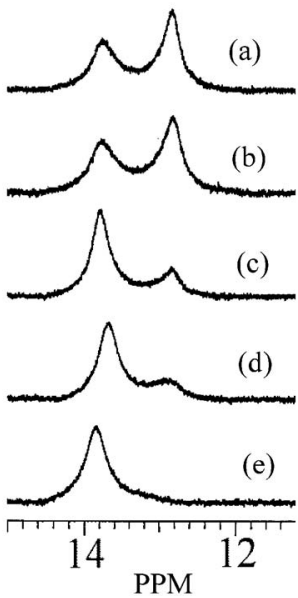

Fig. 26. ${ }^{19} \mathrm{~F}$ NMR Spectra of $1.0 \mathrm{~mm}$ TFZ with $1.0 \mathrm{~mm}$ BSA (A) and 1.0 mm HSA (B), in the Presence of Several Competitive Ligands

Competitive ligands: (a) none, (b) $1.0 \mathrm{~mm}$ warfarin, (c) $1.0 \mathrm{~mm}$ L-tryptophan, (d) $0.15 \mathrm{M} \mathrm{NaCl}$, (d) $6.0 \mathrm{~mm}$ oleic acid.

いずれについても高磁場側のシグナルが大幅に減少 しており，高磁場側のシグナルは BSA，HSA の Site II に結合した TFZ のものであることが判明し た。両スペクトルとも新たなシグナルは現れておら ず，低磁場側のシグナル強度が増加していることか ら， Site II から離脱した TFZ は低磁場側シグナル が示す Siteへ移行したと考えられる。

Figure 26A(d)， B (d) は $0.15 \mathrm{M} の \mathrm{NaCl}$ を加えた 結果である。 L-tryptophan を添加した場合と同様に Site II 由来のシグナルが大幅に減少し低磁場側のシ グナルが増大している．また，低磁場側のシグナル が若干高磁場シフトしていることから， Site I から 離脱した TFZ は低磁場側シグナルの Site へ移行す るが，非結合の TFZ も増加していることが分かっ た。この結果は, 2 次微分分光法で示された $\mathrm{NaCl}$ 存在下では BSA に対するフェノチアジン系薬物の 結合定数が約 $30 \%$ 程度低下する47)ことの原因をよ く説明している。また， $\mathrm{NaCl}$ 未添加では BSA と HSA では TFZ の結合の Site に対する分布が異なつ ているが，生理的条件である $\mathrm{NaCl}$ 存在下ではほぼ 同じ分布を示し，BSA と HSA で TFZ 結合に対し て差がなくなっていることが示され，興味深い。

ついで，Fig. 26A (e)，B (e) は長鎖脂肪酸の一種 である oleic acid をアルブミン 1 分子当たり 6 個結 合した HSA，BSA を用いた結果である。アルブミ
ンは 1 分子当たり最大 6-7 分子の長鎖脂肪酸を結合 する50,51) と言われており，長鎖脂肪酸結合サイトが 埋まった状態での TFZ 結合の様子を知る目的で行 った. Figure 26Ae，Be から分かるように Site II に 結合した TFZ のシグナルは消失し，oleic acidによ り TFZ はほぼ完全に Site II から追い出されている ことが分かる。しかしながら，非結合型のシグナル は生じておらず，低磁場側のシグナルに線幅に若干 の減少がみられることから，結合量の減少があるも のの, oleic acid が 6 分子結合した HSA，BSA に おいても，TFZ のアルブミンへの結合は維持され ていることが分かる. ${ }^{49)}$

\section{4-2-2. 非ステロイド系抗炎症剂 Niflumic Acid} の HSA 結合の解明52) 続いて，含フッ素薬物で 非ステロイド系抗炎症剤である niflumic acidの HSA 結合について ${ }^{19} \mathrm{~F} \mathrm{NMR}$ を用いて種々の検討を 行った. HSA については近年 Site I は 3 個の領域 (Site Ia，Ib，Ic) ${ }^{53)}$ を有することが提唱されてい るが，今回筆者らは niflumic acid は Site Ia と Site Ib に約 1：3の比率で結合すること，また競合リ ガンドにより Site Ia から Site Ibへ，あるいはその 逆の移動が起きることを明らかにした。また，本研 究において， niflumic acid が Site Ia，Ib 結合薬物 であることが明らかとなつたので，フッ素を含まな い薬物についても niflumic acid をプローブとして 利用することにより ${ }^{19} \mathrm{~F} \mathrm{NMR}$ を用いて極めて簡便 に結合サイトを調べることができることを示し た. ${ }^{52)}$

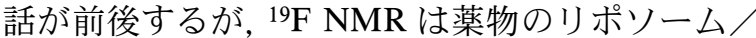
水系の分配係数測定へも応用が可能である。ベンゾ ジアゼピン系薬物である flunitrazepam, flurazepam, フェノチアジン系の trifluoperazine はいずれもフッ 素原子を有しており，その ${ }^{19} \mathrm{~F} \mathrm{NMR}$ シグナルは水 相から PC 二重膜へ移行することによって化学シフ トが変化するため，それを利用して分配係数を算出 した. 得られた分配係数は 2 次微分分光法によって 求めた值とよく一致した. ${ }^{54)}$

また，PC二重膜へ移行しても化学シフト変化を 起こさない $\mathrm{TFZ}$ については，水相中と $\mathrm{PC}$ 二重膜 中とで縦緩和時間 $\mathrm{T}_{1}$ が異なることを利用して分配 係数を測定した. ${ }^{55)}$

本法は含フッ素薬物に限られるが，脂質相と水相 で吸収スペクトルに差がない場合の分配係数測定に 
用いることができる方法であり， ${ }^{19} \mathrm{~F} \mathrm{NMR}$ 法の新 たな利用法を開いたといえる.

\section{5. おわりに}

以上，筆者らは，パソコンを利用した微分分光法 を開発し，薬物分析において従来の吸光分析では困 難であった課題を解決して吸光分析の応用範囲を拡 大した。 また，薬物と生体マクロ分子との相互作用 について，2 次微分分光法を適用することにより定 量的な知見を得，また，NMR 法を活用するによつ て, 詳細な構造化学的知見を得, 相補的な解析を行 つた.

謝辞京都薬科大学薬品分析学教室で筆者とと もに研究を推進したスタッフ, 大学院生，特別実習 生，留学生の皆さんに深謝する.

\section{REFERENCES}

1) Talsky G., Mayring L., Kreuzer H., Angew. Chem. Int. Ed. Engl., 17, 785-799 (1978).

2) Kitamura K., Bunseki, 1994, 991-998 (1994).

3) Kitamura K., Majima R., Anal. Chem., 55, 5456 (1983).

4) Rojas F. S., Ojeda C. B., Pavon J. M. C., Talanta, 35, 753-761 (1988).

5) Savitzky A., Golay M. J. E., Anal. Chem., 36, 1627-1639 (1964).

6) Kitamura K., Morita E., Hozumi K., Yakugaku Zasshi, 105, 161-165 (1985) .

7) Kitamura K., Hozumi K., Anal. Chim. Acta, 172, 111-118 (1985).

8) Kitamura K., Hozumi K., Anal. Chim. Acta, 201, 301-304 (1987).

9) Glombitza B. W., Schmidt P. C., J. Pharm. Sci., 83, 751-757 (1994).

10) Sawyer M., Kumar V., J. Chromatogr. Sci., 41, 393-397 (2003).

11) Kitamura K., Takagi M., Hozumi K., Chem. Pharm. Bull., 32, 1484-1490 (1984).

12) Kitamura K., Mabuchi M., Fukui T., Hozumi K., Chem. Pharm. Bull., 35, 3914-3917 (1987).

13) Kitamura K., Hatta M., Fukuyama S., Hozumi K., Anal. Chim. Acta, 201, 357-361 (1987).

14) Ueno T., Urakami K., Azuma A., Umemoto K., Kanbe M., Kitamura K., Yakugaku Zass- $h i, \mathbf{1 2 5}, 807-814$ (2005) .

15) Kitamura K., Kitade T., Mabuchi M., Mizuochi M., Goto K., Bunseki Kagaku, 42, 581-585 (1993).

16) Kitamura K., Takenaka M., Yoshida S., Ito M., Nakamura Y., Hozumi K., Anal. Chim. Acta, 242, 131-135 (1991).

17) Kitamura K., Imayoshi N., Anal. Sci., 8, 497501 (1992).

18) Morelli B., Anal. Let., 21, 759-776 (1988).

19) Kitamura K., Takahashi T., Hozumi K., Sato T., Chem. Pharm. Bull., 26, 256-259 (1978).

20) Kitamura K., Kano H., Yoneyama K., Hozumi K., Mol. Pharmacol., 20, 124-127 (1981).

21) Kuroda Y., Kitamura K., J. Am. Chem. Soc., 106, 1-6 (1984).

22) Ohyashiki T., Karino T., Matsui K., Biochim. Biophys. Acta, 1170, 182-188 (1993).

23) Kitamura K., Yamamoto M., Murakami J., Kobayashi T., Kitade T., J. Colloid Interface Sci., 200, 250-252 (1998).

24) Kitamura K., Kishino T., Hozumi K., Chem. Pharm. Bull., 27, 1264-1267 (1979).

25) Kitamura K., Noguchi M., Nishiyama C., Kobayakawa K., Fukui T., Kuwahara Y., Hozumi K., Chem. Pharm. Bull., 37, 11471150 (1989).

26) Kitamura K., Takegami S., Kobayashi T., Makihara K., Kotani C., Kitade T., Moriguchi M., Inoue Y., Hashimoto T., Takeuchi M., Biochim. Biophys. Acta, 1661, 61-67 (2004).

27) Kitamura K., Fujitani K., Takahashi K., Tanaka Y., Hirako S., Kotani C., Hashimoto T., Takegami S., J. Labelled Cpd. Radiopharm., 43, 865-872 (2000).

28) de-Paula E., Schreier S., Braz. J. Med. Biol. Res., 29, 877-894 (1996).

29) Garcia D. A., Perillo M. A., Biochim. Biophys. Acta, 1324, 76-84 (1997).

30) Roger J. A., Choi Y. W., Pharm. Res., 10, 913-917 (1993).

31) Avdeef A., Box K. J., Comer J. E. A., Hibbert C., Tam K. Y., Pharm. Res., 15, 209-215 (1998).

32) Welti R., Mullikin L. J., Yoshimura T., Helmkamp Jr. G. M., Biochemistry, 23, 60866091 (1984).

33) Kitamura K., Imayosh N., Goto T., Shiro H., Mano T., Nakai Y., Anal. Chim. Acta, 304, 
101-106 (1995).

34) Takegami S., Kitamura K., Kitade T., Hasegawa K., Nishihira A., J. Colloid Interface Sci., 220, 81-87 (1999).

35) Kitamura K., Goto T., Kitade T., Talanta, 46, 1433-1438 (1998).

36) Takegami S., Kitamura K., Kitade T., Kitagawa A., Kawamura K., Chem. Pharm. Bull., 51, 1056-1059 (2003).

37) Wode-Helgodt B., Alfredsson G., Psychopharmacology (Berlin), 73, 55-62 (1981).

38) Kohl H. H., Brune G. G., Himwich H. E., Biochem. Pharmacol., 13, 539-541 (1964).

39) Takegami S., Kitamura K., Takahashi K., Kitade T., J. Pharm. Sci., 91, 1568-1572 (2002).

40) Omran A. A., Kitamura K., Takegami S., ElSayed A.-A. Y., Abdel-Mottaleb M., J. Pharm. Biomed. Anal., 25, 319-324 (2001).

41) Funakoshi T., Takegami S., Kitade T., Kitamura K., Abstracts of papers, the 123th Annual Meeting of the Pharmaceutical Society of Japan, Nagasaki, March 2003.

42) Hansch C., Leo A., Hoekman D., "Exploring QSAR," American Chemical Society, Washington, DC, 1995.

43) Takegami S., Kitamura K., Kitade T., Takashima M., Ito M., Nakagawa E., Sone M., Sumitani R., Yasuda Y., Chem. Pharm. Bull., 53, 147-150 (2005).

44) Omran A. A., Kitamura K., Takegami S., Kitade T., El-Sayed A.-A. Y., Mohamed M. H.,
Abdel-Mottaleb M., Chem. Pharm. Bull., 50, 312-315 (2002).

45) Peters Jr. T., "All about albumin,” Academic Press, New York, 1996.

46) Kitamura K., Mano H., Shimamoto Y., Tadokoro Y., Tsuruta K., Kitagawa S., Fresenius $J$. Anal. Chem., 358, 509-513 (1997).

47) Kitamura K., Omran A.A., Nagata C., Kamijima Y., Tanaka R., Takegami S., Kitade T., Chem. Pharm. Bull., 54, 972-976 (2006).

48) He X. M., Carter D. C., Nature, 358, 209-215 (1992).

49) Kitamura K., Kume M., Yamamoto M., Takegami S., Kitade T., J. Pharm. Biomed. Anal., 36, 411-414(2004).

50) Richieri G. V., Anel A., Kleinfeld A. M., Biochemistry, 32, 7574-7580 (1993).

51) Bhattacharya A. A., Grune T., Curry S., $J$. Mol. Biol., 303, 721-732 (2000).

52) Kitamura K. , Omran A.A., Takegami S., Tanaka R., Kitade T., Anal. Bioanal. Chem., 387, 2843-2848 (2007).

53) Yamasaki K., Maruyama T., Kragh-Hansen U., Otagiri M., Biochim. Biophys. Acta, 1295, 147-157 (1996).

54) Omran A. A., Kitamura K., Takegami S., Kume M., Yoshida M., El-Sayed A.-A. Y., Mohamed M. H., Abdel-Mottaleb M., J. Pharm. Biomed. Anal., 30, 1087-1092 (2002).

55) Kitamura K., Yamamoto M., Takegami S., Sugiura M., Talanta, 49, 261-265 (1999). 